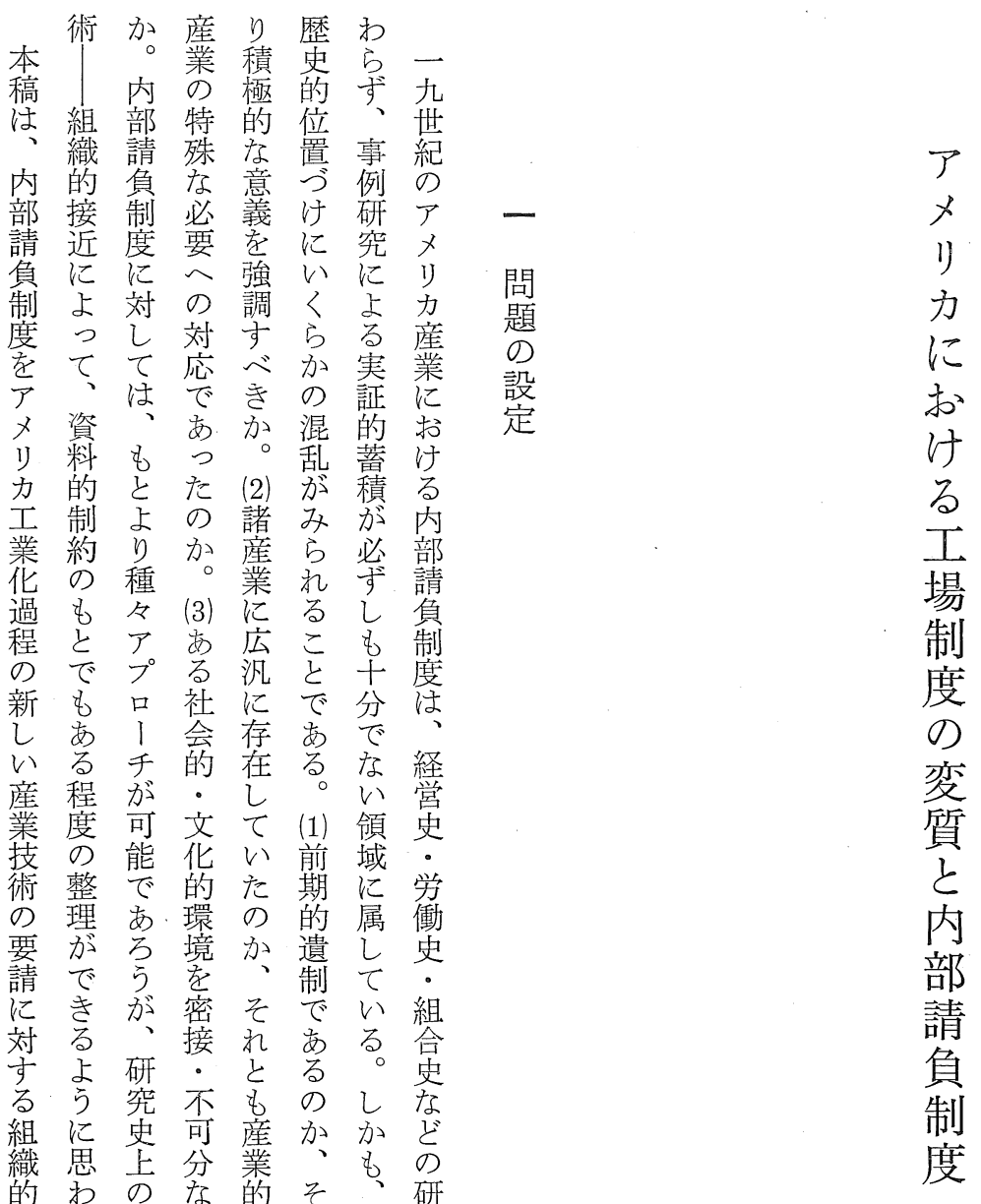

塩

見

治

ていたた专度の

考ての限しでに

察はからて、も

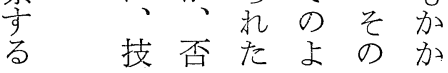


製のと制の当の无でブこ市視

鉄工起にこ度工寻設場㐫・㔯け一 角

業場源严この業る定内加

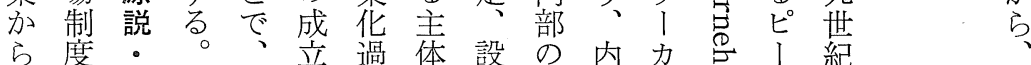

与度・立過体設の内力总 紀

真へ移従・程で備部部 I草スの

鍮の転 来普 に

品入研に際た全業人导コス制研負

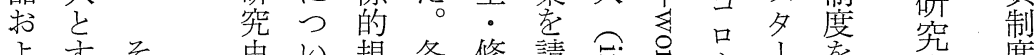

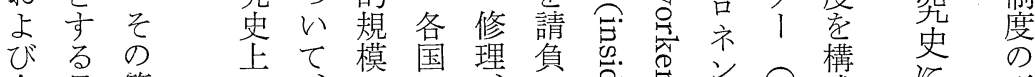

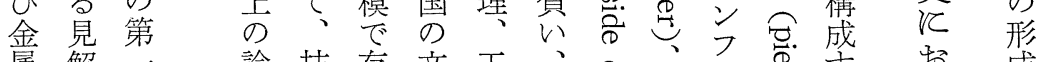

属解

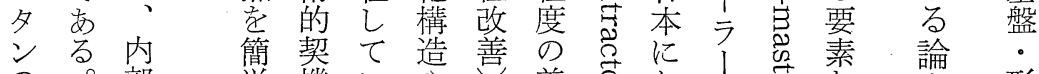

の 0 部 簡 契て 造 善 の

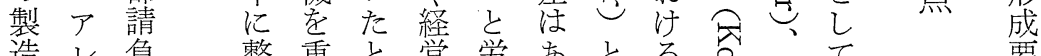

造レ負整重と営労あとる。゚

にン制理視い風務れて親名ジ备

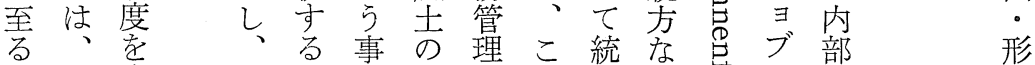

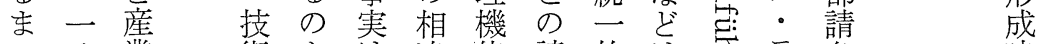

で八業術す, 違能請的は、壳テ負時

の六革、負に、息、期

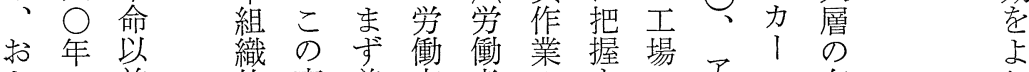

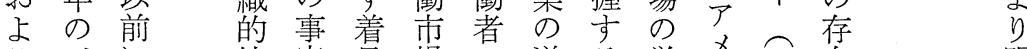

そバに接実自場の遂る労 リ で在明

大 1 近にさ。調行こ働

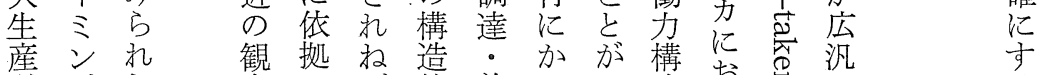

単ガた。点しば的養かで成注导に尚

位么問てな特成わきにる 確

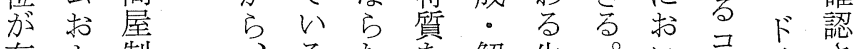

存よ制、るな孛解生。いコンイさ

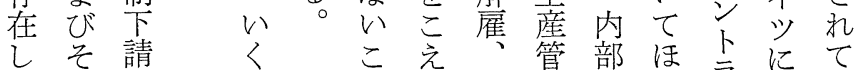

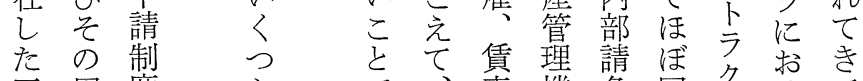

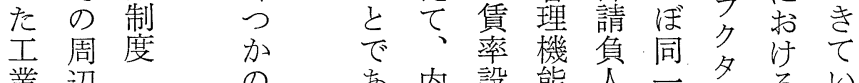

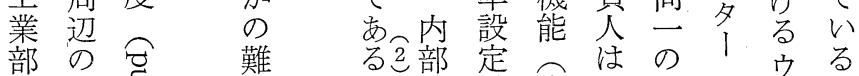

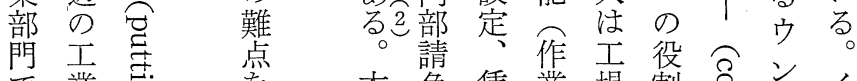

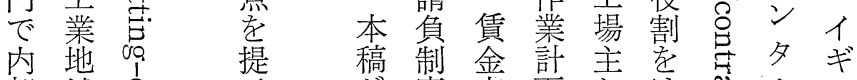

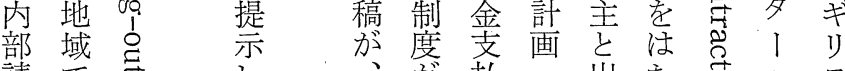

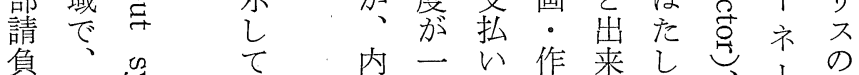

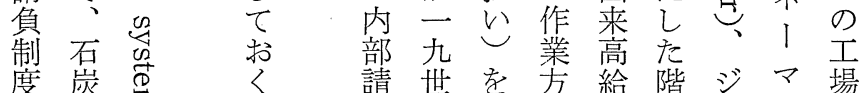




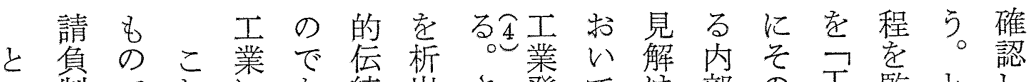
ろ制でれ れ

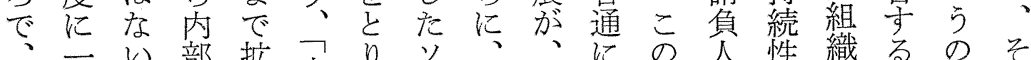

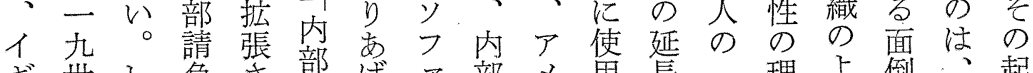
ギ世し負さ部げア部メ角長 リ紀加制机請て、請りさ線激丒り擘源

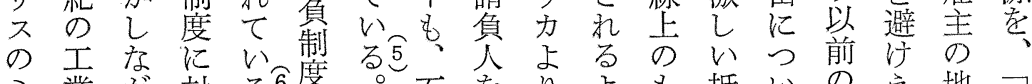

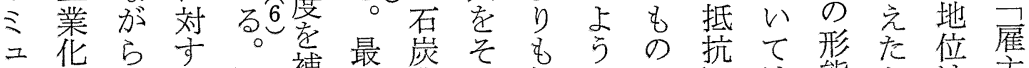

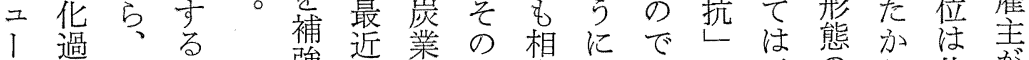

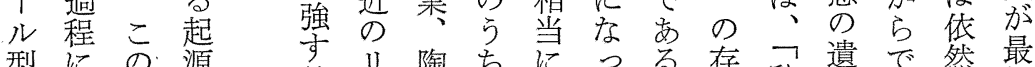

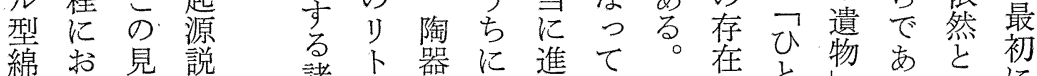

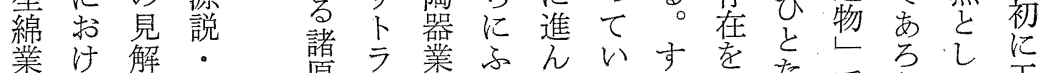

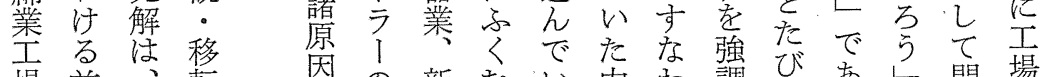
場前、転因の新むい内肉わ調びあし問場 は期単説研聞一た部ちし成り、と屋省 確的に湥印九不請彼て 立、説の建

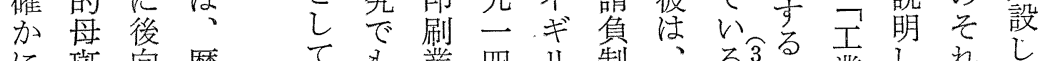

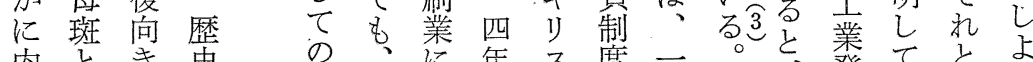

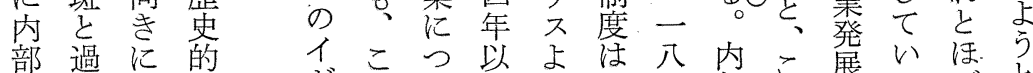

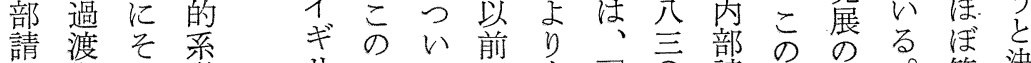

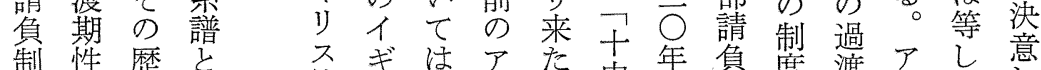

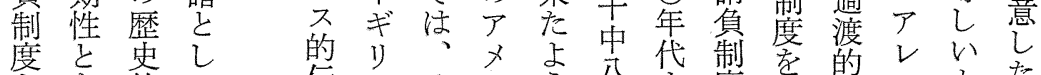

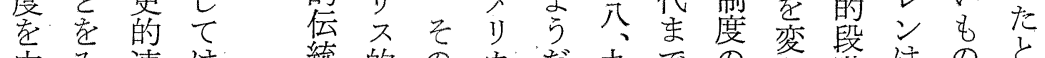

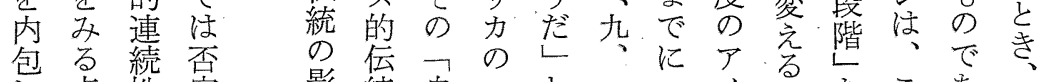

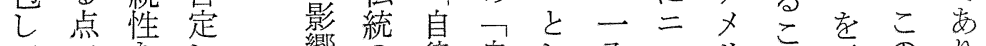

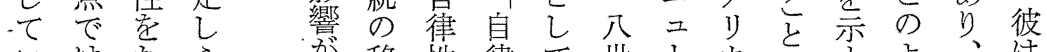

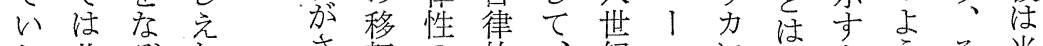
た共ぞなさ転の的、紀・灘もうと当 が通っいら・諸労イ後イおお朝のなの 然

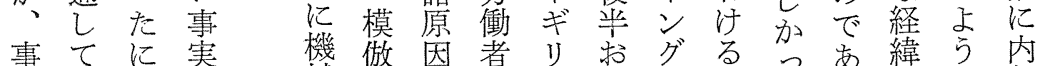
態いす械のの起たるるをに部

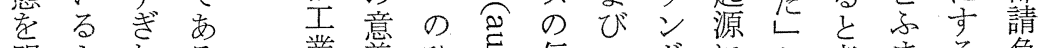
明よなる業義ひ灾伝一ドにと考まる 負

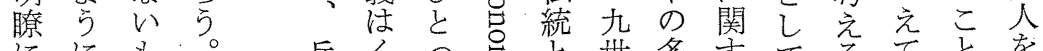

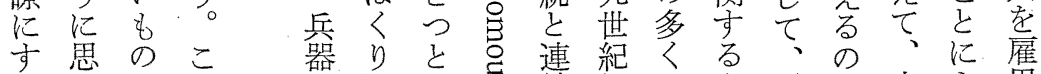

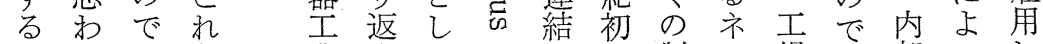
たれ省さてをさ頭製イ場あ部っし

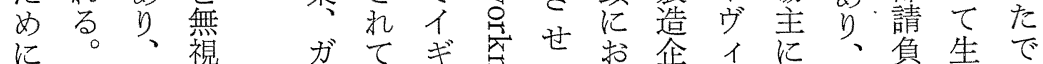

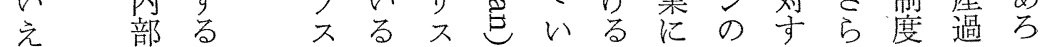




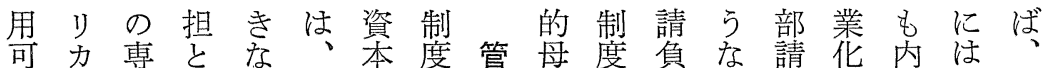
能の門資利主上理斑の制歴負を部存そ と産化本点た義の回盐位度制達請在机

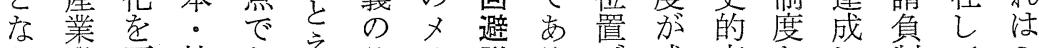
り、発可技变管々リ説亏方成事と制てミ

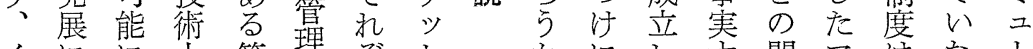
イにに上管理ぞ卜 加に守関アはな1 ン即すの理の方机を第。混なな係メ成いル フしる知回方のよ法乱か性り立へ精

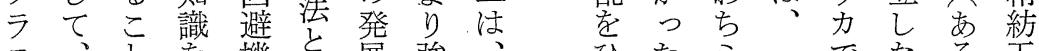
ス、を機六展強、ひたミ一でなる兄 卜内内能わ段調経:きの二九はかい程 ラ部 (5) 部学な階す嫦打か、、世、つはを

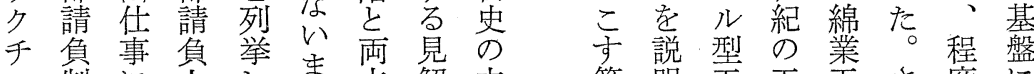
二制に人し立解立第明志工志さ度に ア度效とてでしで場章で場業場らの成 がのしの

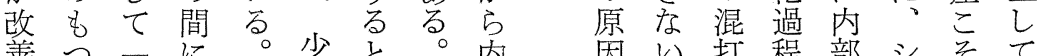

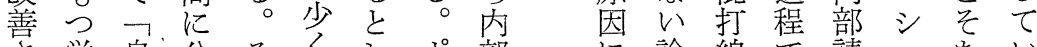
さ労自分そくし迆部に論綿で請ユあい れ務動つれとな今請な理汃は复口秃た る管的こらもが、負つ的ら世制ッ例の 一理なと注管ら㫼て枠粗界度 八機刺、、理も注度紡的はル的あ 四能激 (3) (1) る、のみ成型でり 年よを襍企避ギそ評鼻な程共立綿票混

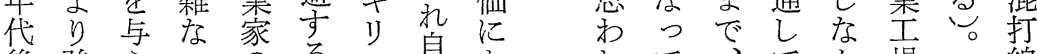

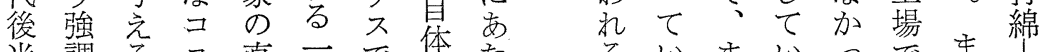
羊調る る

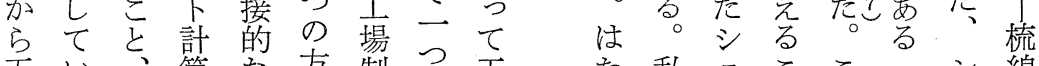
五いく、算な方制の坦た私二ここすシ 綿

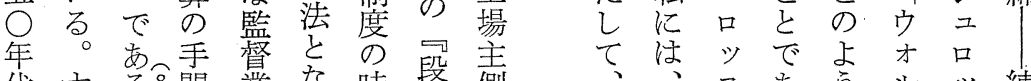

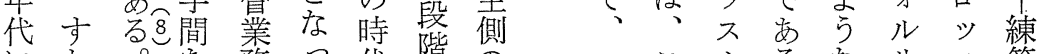

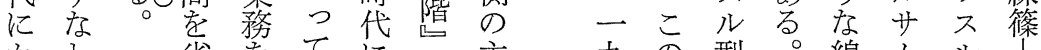

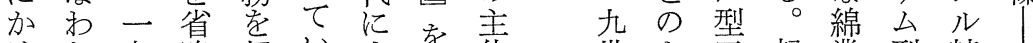
けち方略軽いま学体世む圭起羓型精 て、減たで型的紀 場源工紡粗 の彼チる守レ残威なのなの説場工工紡 金はヤこると存る条内枠全。類場程工

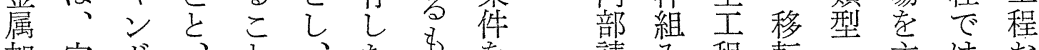

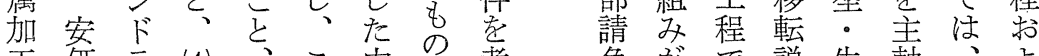

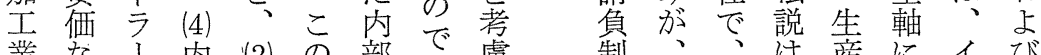

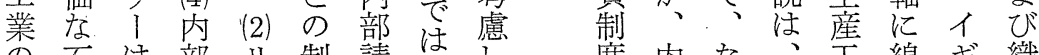
の石は部り制請な岕度内な、吉綿ギ織

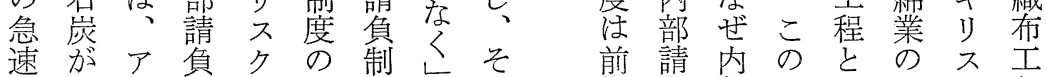

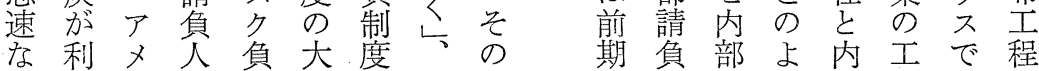




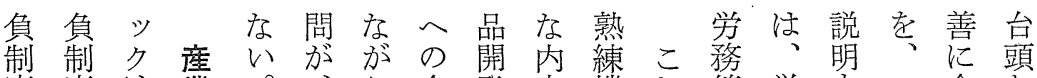

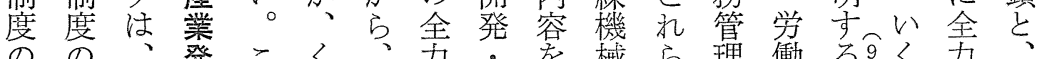

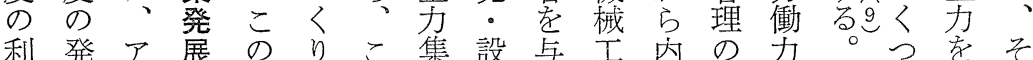
用達入促点返こ中備光と部複のチ加集の はのり進でさで永改たの請雑雇ヤの製 、要力説、机も、善こパ負な用ン部し品

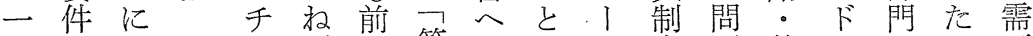
つで拈ば述管のにト度題養ラのた要 のあけ第ンなし理熱こ十に站成け職め、の 重るるる 加属、以部避商義ッる意理内ち理七

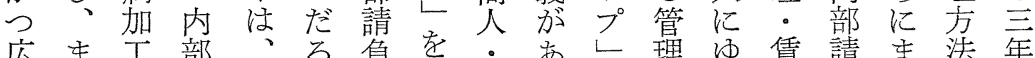

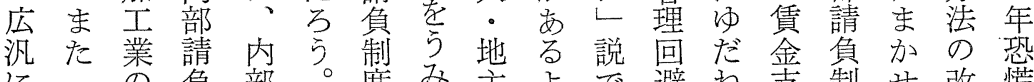
にコの負部。度 文主よで避袮支制せ改梳 用需需制請あのだ川うも説る払度た善に

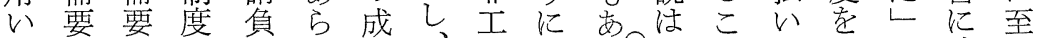

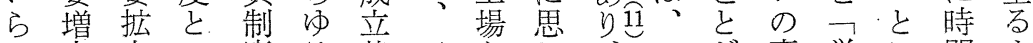

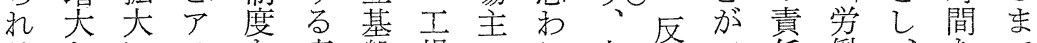
万とにメ学産盤場の㧈内面で任衝、をで 制大対り 金業に管作る。部璱さを組さささ 度規応力属で対理業。請、たも織らく順 へ模し 産加、寸 機現確負バレつのに余調

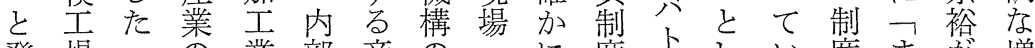
発場 $の$ 業部産の ヘ

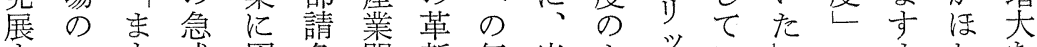

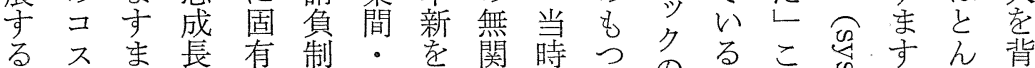
る

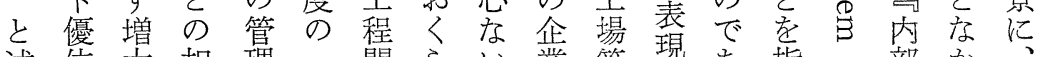
述位大相理 ᄀ間らい業管罠要指。部か 、 ベと毛問管でせし家理 角る㒀摘請っこ

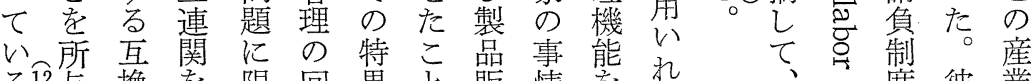

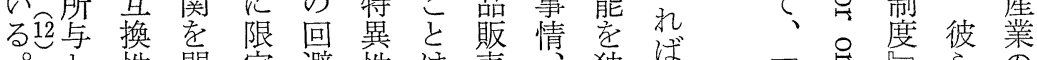

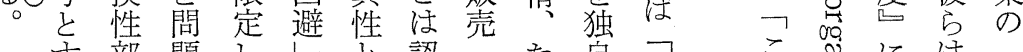

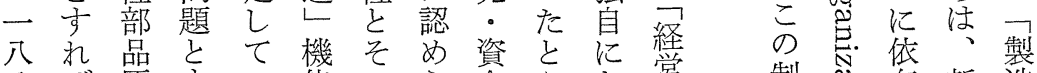

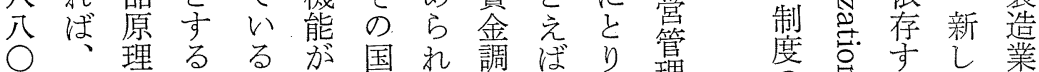

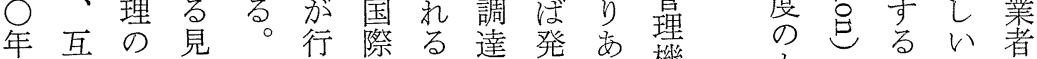
の換利解使的でな明げ機を能を王を

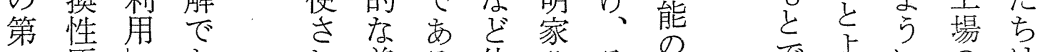

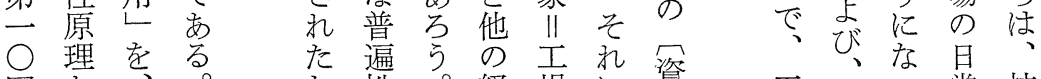

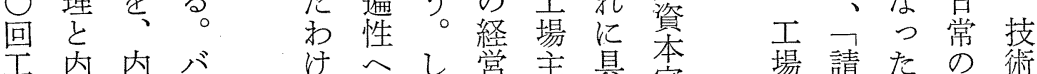

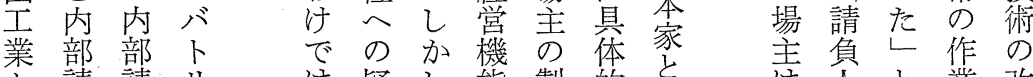

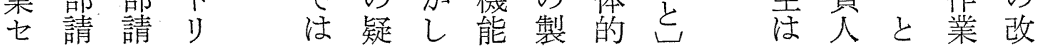


をる社後のびのにイ制的っ内ラは評専ン 調労口述生生工位ン度方て部门、価門少 整さ|の産産程置ダ注法い請り三で的 ス しえ ズと量量改しス、でた負ズ○きさで 、い夕预のの善てト衰㐬し制么世る作ア 製とウり推急能おり退るこ度を紀だ機メ

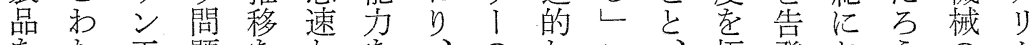
をな工題をなを、のなこ、極発就うの力 生い場吕紹增評多事小と儿限し 忊し発に

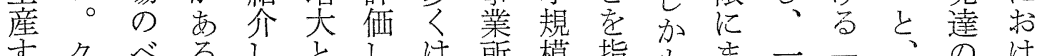

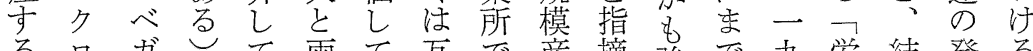

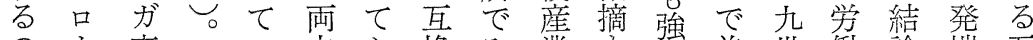
の 車棟立か換み業劣調美世衝論端互

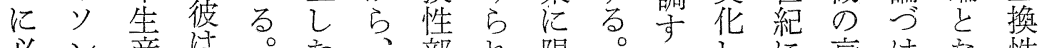
必ン産は。た、部れ限。今゙袁けな性 要の台、こし最品、定つきて文退てっ生 で主数一のこ後后こさい重いらしいた産

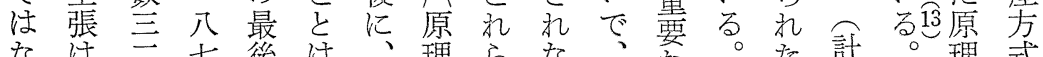
なは三七後は、理らな、な。た計。理式

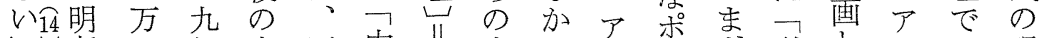

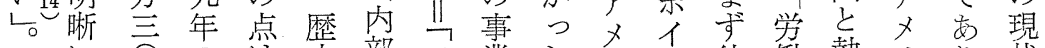
に○の注史部ア業たりン彼衝熱りり、状 要○シ、的請丈所以力注者行力、孝

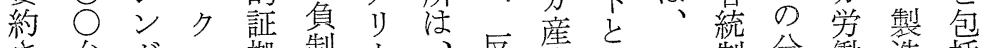

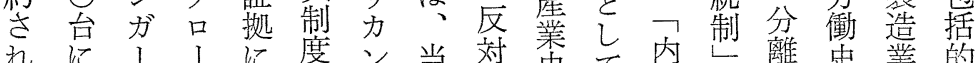

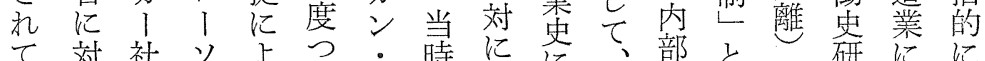

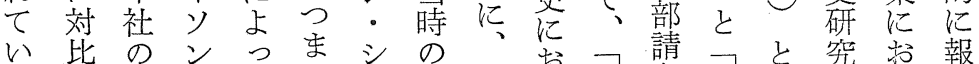

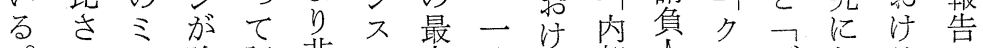
せシ強証悲テ娶八る部全ラビおるし

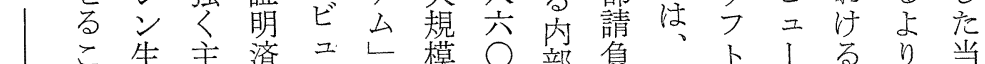

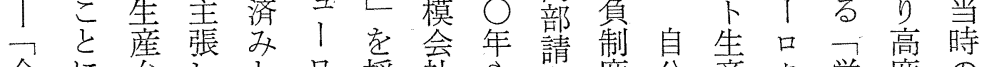
今に台しと採社や售度分産ク労度の 日よ数たしク用に二制夰のしラ衝な観 存つ四かてラし属八蔗生領のシ者生察 在て三っ、シてて九草産域意门統産者

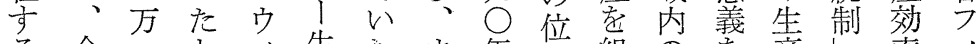
る今一とイ生たま年置組のを産流々 ビ日一こン産とたの真織生積疓論を.ッ ユの六ろ千がい当ア役化産極さの寒千 I $\mathrm{G}$ 七 で エ

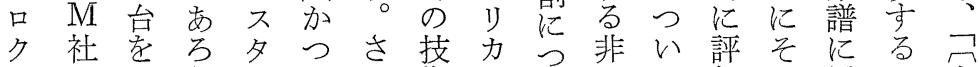
ラの—う】てら術のいビて価の属も内

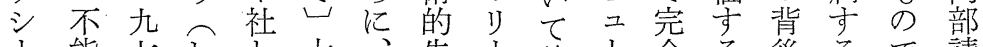
l 能七しと大、先 ! 論 1 全る後るで請 層率一かシ量内導デ盟口な立にク市負 はを年しン生部者イ、ク責場要口る制

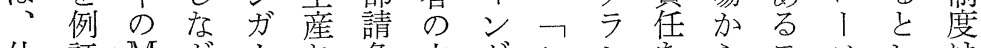

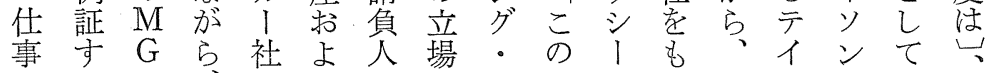


ろる観は て代制ア部行極らをた 地い而 メ の。注述説よメ何力制たり置とるをら 六、1 の ら リ ら産度め力し説の認の ルすす却にカ加業はににてくにめ見 ソ ベン源多思でのの、彼おい点対る 解

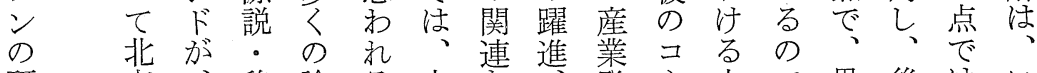
研東、移論る大孝登六内、゙異後はい 究部内転者。量もイ展毛部市な者共す

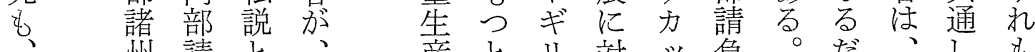

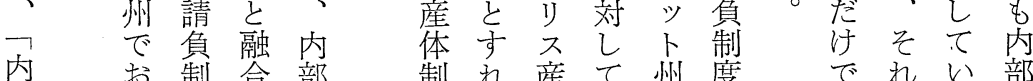
内拉制合部制れ産て州度でれい部 請应な 負 負わ放制

製机二ら度

度さき

た・の盤

明のイ制と

ら で ン 度し

に 劣 ラ 地文

北文域化

查岗ド性 構

の 請 ス 主

機負夕張労

械制イ 守 働

のば業同ミの

発、のしだ歴

達こ停前ル史

にの滞向夕的

よ制がきウ

つ度誰のンパ

て高役正ン

内正目割場

部区 に

負重明揮 大

制のらしし九

度役かえた

の割とたの年

無をなでがに

機演つあ 端 ス

能したる初夕

I 度ルる市

場䚾 $\leftarrow$ 点場

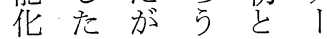

にととでの

がのでも尔わ文

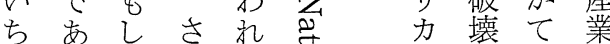

普つ呼は特

及 て $几$ 共質

し 地よ通䒚

早万仮 ら、党

< 5 に

発加。二 二

い. 域うて 題

た・性に占いに

の の 本徉兄

女質来す心

る 的のでる

レなアに。

と意メーこ

乙義り九れ

て はカ世ら

い、何に紀の

る でお寿見

呍㐫けの解

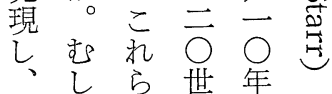

そろの紀代が

の私産のに軍

制に業転及刀

約は. 動 換 ぶの

要、向期。政

因一ににこ府

に八内向の契

転八部つ間約

化 $\bigcirc$ 請て、内遂
あ妾る。請 る認 ○負 こす、だ し.資、大 七本前量 両家者生 者テは袁 、 内 向 一 I 部 寸 九リ請る 世 ズ負ア 紀 ム制 メ 末に度り アよが力 メる や.の リ破加産 管的こ動 理攻の向 運撃動と 動に向両 のよの 立 歴己制し 的こ要々 評の因れ 価制へと に度とと 标吕転\& 、死化に 七滅守普 闻过主 
経営史学

䘚 1 アメリカにおける内部請負制度導入の企業

\begin{tabular}{|c|c|c|c|}
\hline 会 社 名 & 所 在 地 & 製 品 & 雇用規模(1900年) \\
\hline $\begin{array}{l}\text { Colt's Patent Fire Arms } \\
\text { Co. }\end{array}$ & Hartford, Conn. & 小銃 & 1,500 人(1860年代) \\
\hline Remington Arms Co. & Bridgeport, Conn. & 小銃 & $1,300-1,400$ 人(1870年) \\
\hline $\begin{array}{l}\text { Winchester Repeating } \\
\text { Arms Co. }\end{array}$ & New Heaven, Conn. & 小銃; 弾薬 & 2,689 人 \\
\hline $\begin{array}{l}\text { Singer Sewing Machine } \\
\text { Co. }\end{array}$ & Elizabeth, N. J. & ミシン & $4,000-5,000$ 人 \\
\hline Waltham Watch Co. & Waltham, Mass. & 時計 & $2,000-3,000$ 人 \\
\hline Baldwin Locomotive Co. & Philadelphia, Pa. & 機関車 & 14,000 人 \\
\hline Lowell Machine Shop & Lowell, Mass. & 綿業機械 & $2,000-3,000$ 人 \\
\hline Whitine Machine Works & Whitinesville, Mass. & 綿業機械 & 1,700 人 \\
\hline Pratt \& Whitney Co. & Hartford, Conn. & 工作機械 & 1,200 人 \\
\hline Reed \& Barton Co. & Tauton, Mass. & 銀細工 & 800 人(1887年) \\
\hline
\end{tabular}

注）この10社のほかに, Eli Whitney の Middletown 工場 (小銃), Brown \& Sharpe の Providence 工場 (工作機械, ミシン), Robbins \& Lawrence の Windsor (工作機械), Wheeler \& Wilson の Bridgeport 工場が内部請負制度を導入していたが, 実態については不 詳。Springfield 連邦兵器廠と Harper’s Ferr 連邦兵器版は, それぞれ 1820 年代に 1 人の内部 請負人を屋い，工程改善を担当させた。これらはすず゙てニュー・イングランドの企業である。

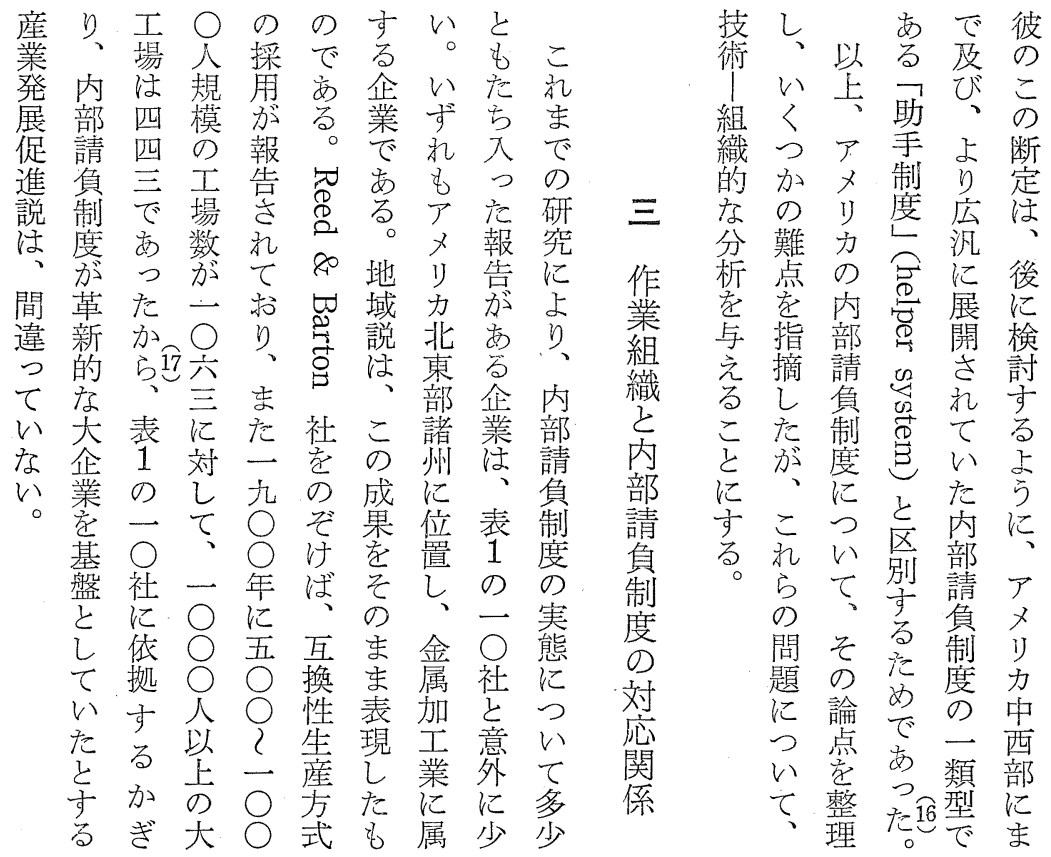


表2 アメリカにおける内部請負制度の産業分布

\begin{tabular}{|c|c|}
\hline 産 & 工 程 内部請負人 \\
\hline 機械工場 & 鋳造工 (moulder) \\
\hline \multirow[t]{5}{*}{ （金属加工工場） } & 機械 (運転) 工 (machinist) \\
\hline & 相互調整組立工（fitter） \\
\hline & 蒸気機関車技師 (locomotive engineer) \\
\hline & ボイラーエ (boiler maker) \\
\hline & パイプ組立工（pipe fitter） \\
\hline \multirow[t]{3}{*}{ 製 鉄 所 } & パドルエ (puddler) \\
\hline & 圧 延 工 (roller) \\
\hline & 加熱炉工 (heater) \\
\hline ガラス工場 & ガラス吹き工 (glass blower) \\
\hline 製紙工場 & 製紙機械運転工（paper machine tender） \\
\hline 陶器工場 & ろくろ工 (jigger) \\
\hline 靴工場 & 縫合機械運転工（stitching machine tender） \\
\hline 既製服工場 & テイラー ; ミシン工 (tailor or machine operator) \\
\hline 印刷工場 & 植 字 工 (compositor) \\
\hline 炭 坑 & 崖 坑 夫 (coal miner) \\
\hline 綿業工場 & ミュール紡績工 (mule spiner) \\
\hline
\end{tabular}

出典）後揭・注18)のこれまでの研究を総括して作成。

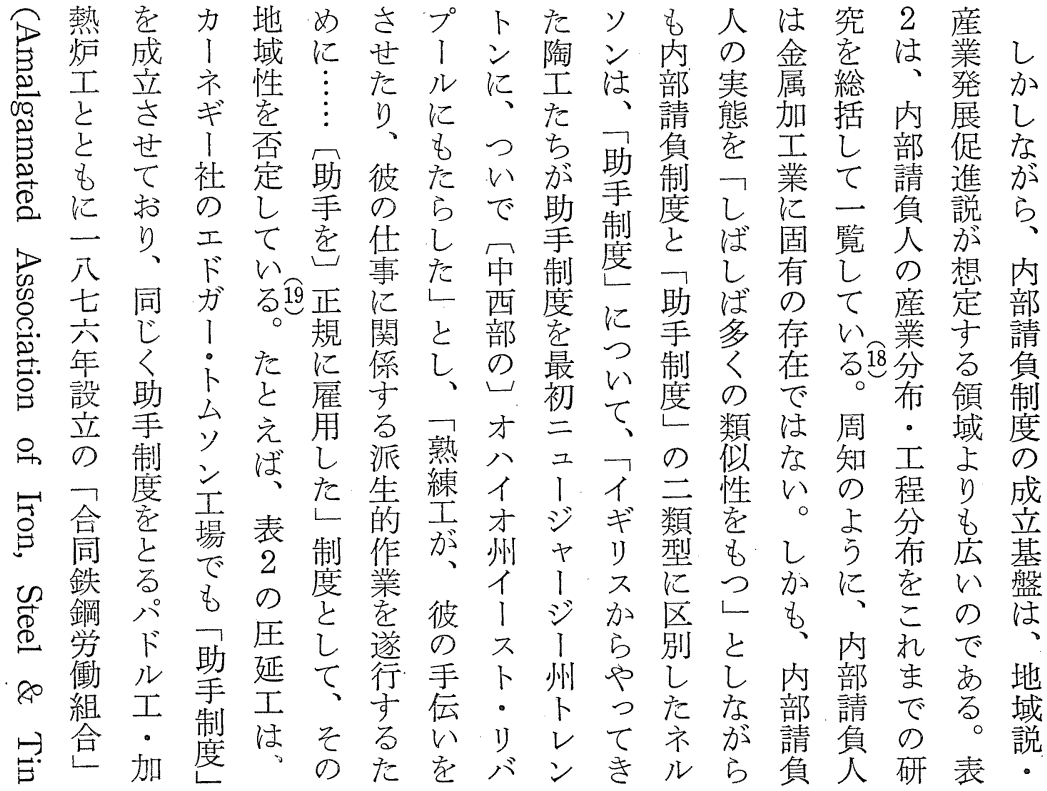


経 営 史 学

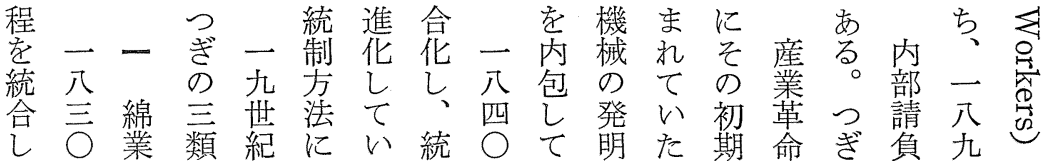

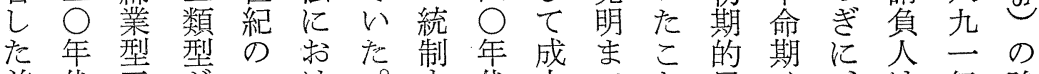

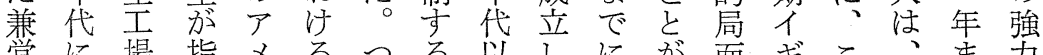

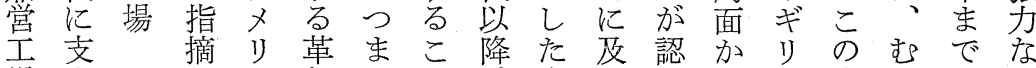
場配でカ新りと堹ぶめら点しにメ で的きにに、、に各産。ら、のをろ鉄ン あなる。成、個よ産シア执技検作鋼 バ

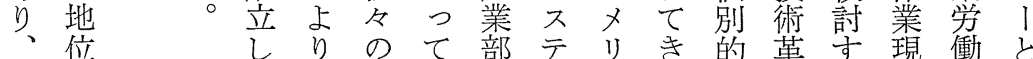
た確生メ術いにののいその。でのっ 精立産り芯加波レ壬当導の主た

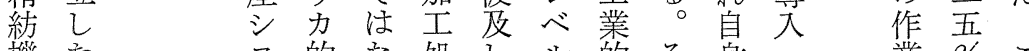
機厄不的㳊処几ル的そ身。業\%こ を学

ウウ

オ オ

I ル

タ サ

1 A

- 型

フ

I 丧

ムは

系

のイ

シ キ

口不

ッの

ス ミ

ル

I

そル

の 型

後 I

さ場

らに

に比

そ ベ

の

倍 紡

の。

能 織

力 I

テなく理てを離れは模

厶特、率い問陸ら 小做

は質そをっ題にはをに

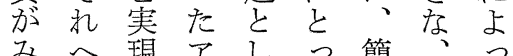

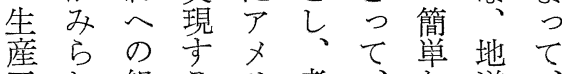

工組るリ考、な道、

程た織点力察こジで一

のの的に工学れグは八

流で対お場加らの市世

れあ応い制えの開る紀

のる21寻て度る個発艻来

維。なはの。別や目上

持

へ方交産

の配き

組置 ら

織方吕テ

的法に山

詨

応

ᄂ

ン ス 場

万人工内

管設 場 の

理

的

視

角

加。

ら标尔

み尔方索
的取立 り

䩸付た

新具なじ

は六いま

無 エイっ

視夫ギた

乙絮学

え

なり的 リ

、ン技力

がグ術の

、精の工

こ紡改業

こ機善化

と景料

で・・過

は専変程

そ的更は

れ交同

万作 < 時
上をの

- 組 組

管 織 合

理しの

上て支

のい部

必たは

要 の

とで中

直亦西

接 る20 部

的

か 中

灾

不比

可分 三

な 蚠

対以

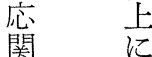

係 ま

の た

も が

とる

で地

登理

場的

店

告

音学 


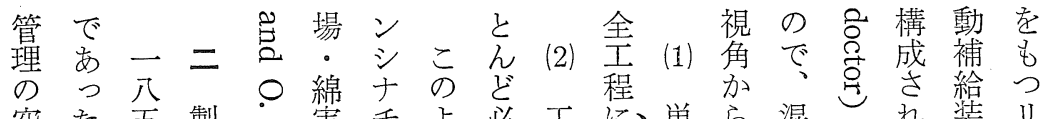

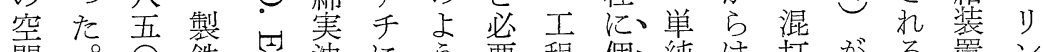

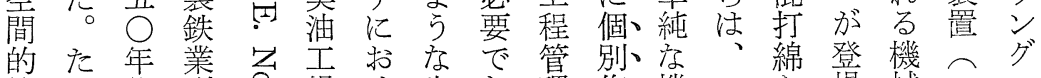

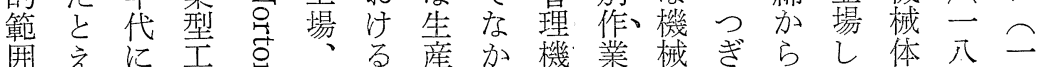

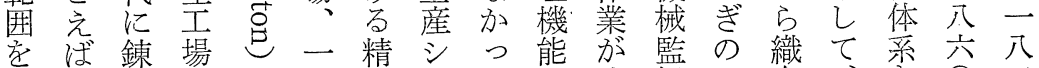

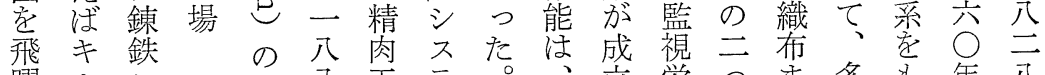

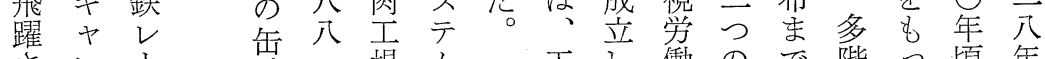
さン 1 詰二場 ム 坦し衝の で階つ垻 年 せブル年、は場て 性の層て 発 たり生貫の二、建い取格原建い方盟 ばア産異ボ八一設た付柺料物た付 か製の場ン七七時。讨重の索。汀

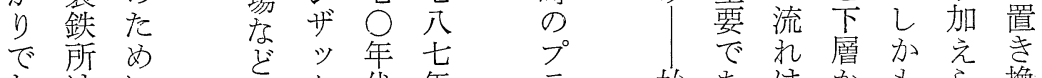

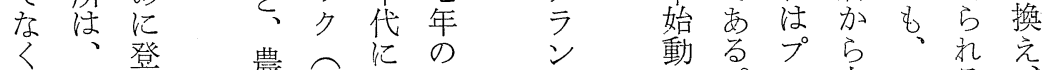
、原晹 加材 し 工 料た 対の 四 象投大 方大銑 高加。 温ら錬 のレー 重 | 貝 量儿製 物の鉄 で 完所 あ成任 るま当 め三時 組、イ 作、ルて 業りには でも 空 危及前 険恕の な設巨 重備大 学 群 生 働 学 に必 シ あ 要 ス た と立

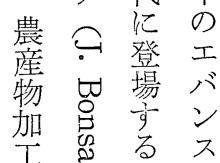

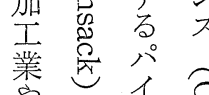

や装の ${ }^{\circ}$.

置巻結莣

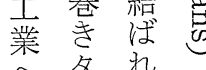

波㣻たの

波バた石製

乙 一貫 精

い空 製 た場 贡 $\frac{\text { 場 }}{\text { 場 }}$

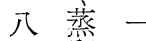

八留入

年酒 六

の場 年

) ・代

Iビの

卜 I 精

ンル 糖

兄醸 場

त्रि 造 亡
ン 動る。プら

設停省八な力 計 步 設と よ 計流年高に ○取に机代速は てりょるるに度よ プはつ綿は、化こ ラすて業、・系 乙 乙 完圣技省切 卜 全場師力断 にでにの争化に ビう統 標設のよ ル ご合準計改る トくさレ士良自 ・采1で灵動 イ自てア专㐫停 動 いウ当包歨

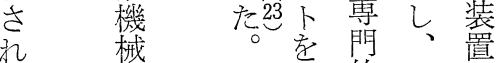
七綿確的全 いに業立な主こ るよ 志し、程八 の て 場普場 が でて 助普場自年 日手只さ名動 常少

的 排

に除

は さ

ほ れ
て タ機

管 いレ械总よ 理っ念加采 
各組機趿—作部自注専

作業運吕方残抒ご車を的八二作卜さ四 業を転認、さょと工亦士機い業回れ八 そ要労知これびに場び作紀械つ辛数る人

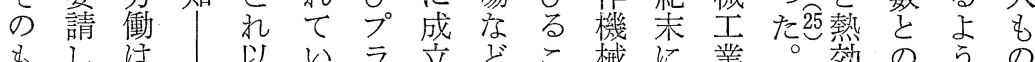

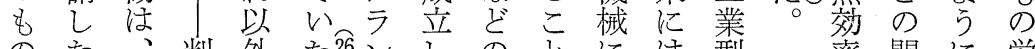
のた、判外た醇立のと型率間に労 を。ふ断の。トた耐によじ圭へのな衝 詨重つ設生詹なるま場の跾る者 象量う業計産消つ生る特密々, 群 と物組操番に亏費た産小 乙を作作機よイ財。亏銃 たと業が械るン産そイの 流りで必工去業れン互 れ报抒要場程れへ、注を換

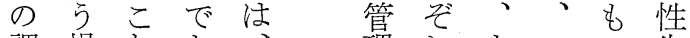
調場なあ、理れま一つ生

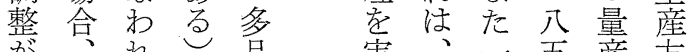

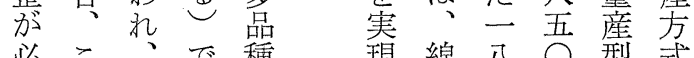
必こで種現綿八门型式 要のまう省梓六年小注 で組たご量て声○代銃、 变作亞々生場年に志漸 り 業換梵産 た代時場次 、班性用を㤂同の計を多 工の原工打、機工成様 程規理作こ数水関場立な 管模が機な多準車。さ専

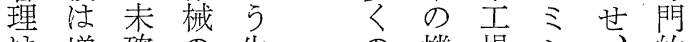
は堌確の生の機場シ 的 生産立機産告珷農主宁作

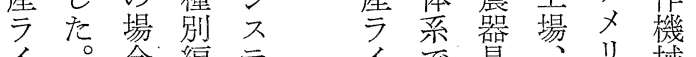
1。合編テ イ

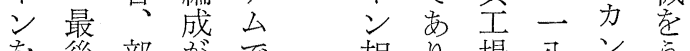
孝後部㔔で想り場分ンう

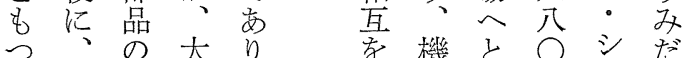
機機手規、総械普年不乙 械種作模機体監及代 I別業な械的視しにムゆ 場機に工運に・てターき に械よ場転調単いイと、 比体るで労整純つプよ一

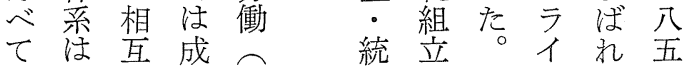

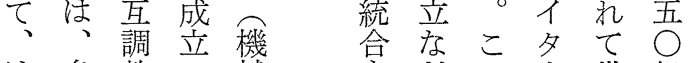
は多整し械导ぞの、世年 る椂組て監るの場工界ま かな立い視課個合場的で に個もたば題別妾。なに

別な、を の・時 熱 つ 配 間 效く 慮的率り 㶳調上だ 要整中去 寸必間の る 要 生で 大亭市 規な物る。 模 つ の 生たバさ 産高兴号 ᄌ

₹ $1 こ$ ムをの は置 二 銅螫 - $<$ 鉄 带架所 鉛否二 菲能 非交 鉄市 金可年 場高渻 や の り 板出鋼 分 銑 V 亏 回 I ㅈ 数 場転用 炉炉 波の少 
第20巻 第 2 号

衰 3 19世紀アメリカ産業における工場の類型構成

\begin{tabular}{|c|c|c|}
\hline 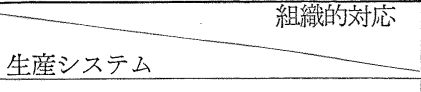 & 個 別 作 業 & プラント設計 \\
\hline 綿 業 型工 場 & $\bigcirc$ & 0 \\
\hline 製鉄業型工場 & $x$ & $\bigcirc$ \\
\hline 機械工業型工場 & & \\
\hline 「アメリカン・システム」(量産型) & $\bigcirc$ & $x$ \\
\hline 多種少量生産型 & $x$ & $x$ \\
\hline
\end{tabular}

注ただし、○は対応あり，メは対応なし。

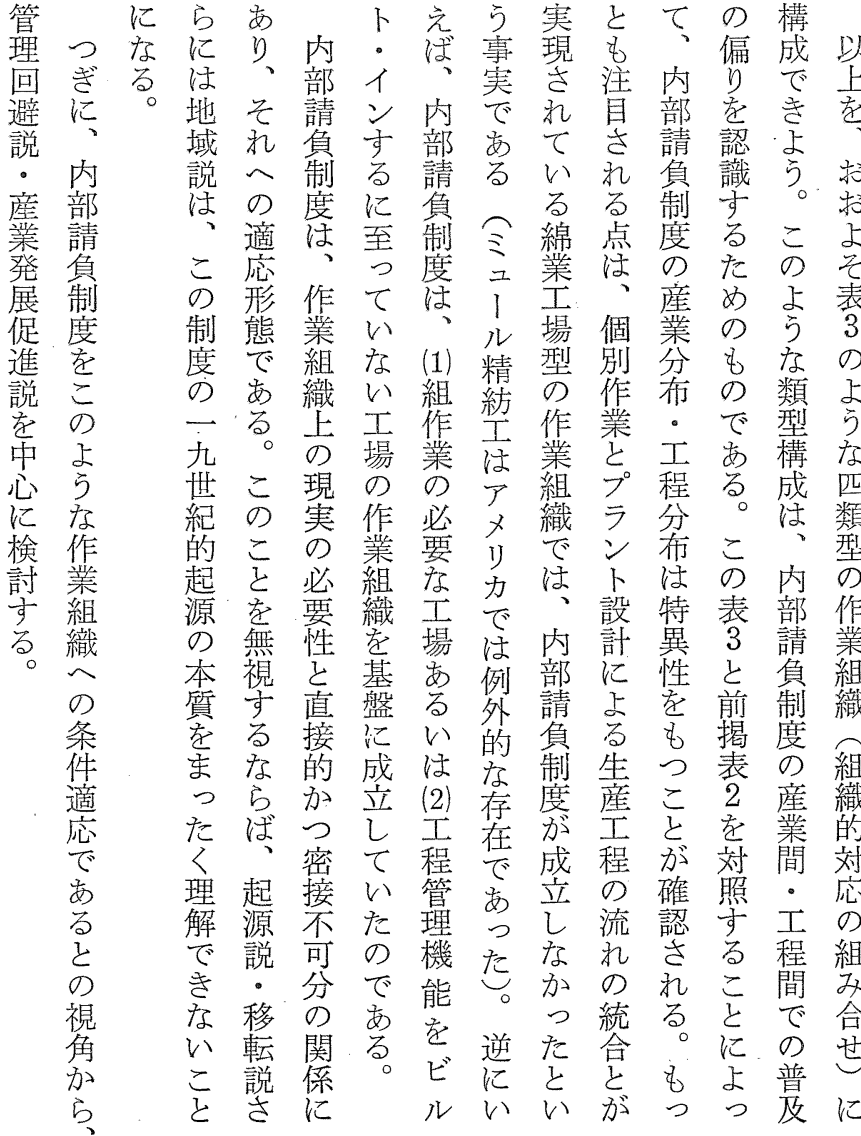


経 営 史 学

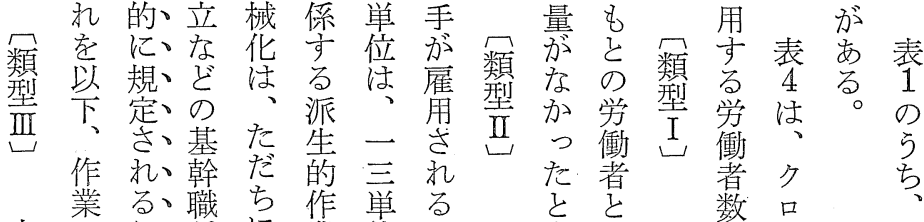

内の組種に業位こ劣变雇学、采

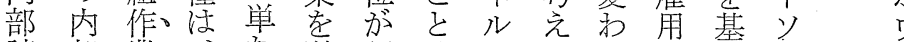

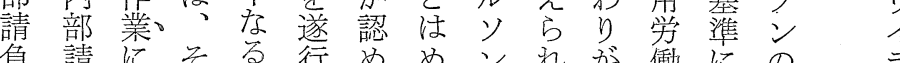

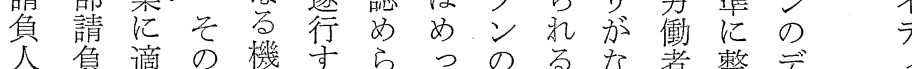

人負適の機すらつのる。な者整デ

にと用執械る光たい。い方㻎「方負

よょさ行監たる。にう䄈制

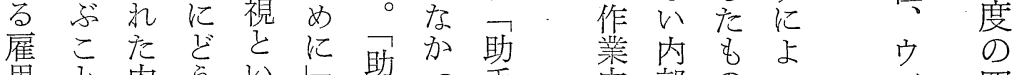

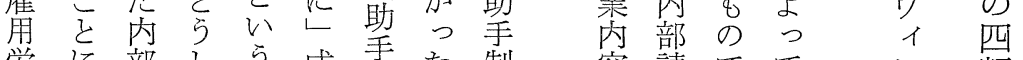

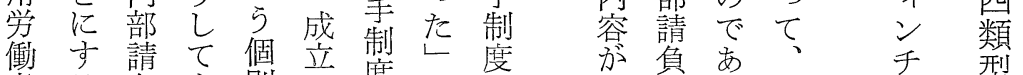

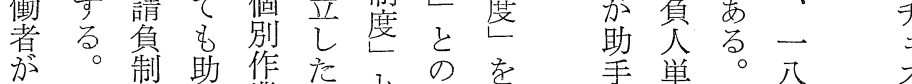

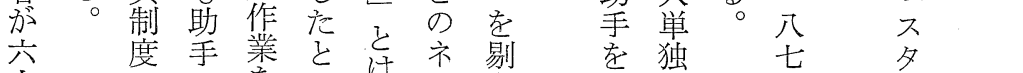

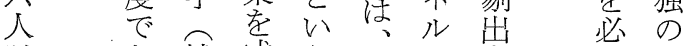

以亦補成ら产守

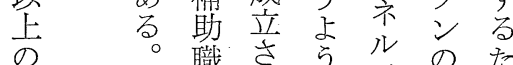

請 技職さ

筫術重た恣定の

算的肪組怔基類

位江必 け作、廟隻型

が規要で業、熟をで

二 定では、練単亦

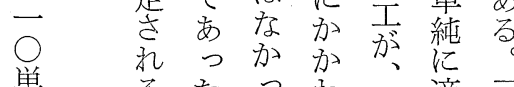

要 請

四

贫

年社

な位

加方

た単

汃位

、蓑

ある

単当たたる尔彼適助

る

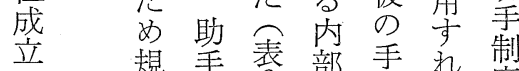

乙 梘 手表部手 記請度

は の

助 場

手 合

の

ホ

ワ 㕮

い少度則を助の

る 小機制势姐む

雇 請

テ

1 社

○

社

に 社

䗆注

け $\supset$

当

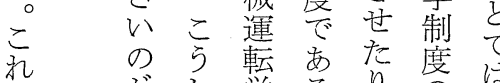

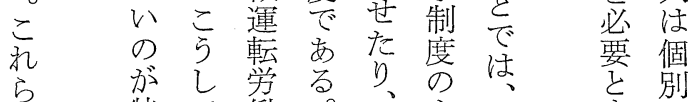

用負のな

を人規和

模新

色き。一彼を六

一家わ相九少に众

応市互世仕あ以

単るて調紀事る声

于 出

請宁

の

こ 術、整 機関負助

る 来

ほ 高

負

は

ど 紷

の 制

㤰度

学京

内 内

部部

請 構

負造

人和

唯墔 
表4 ホワイティン社の内部請負職場(1874年)

\begin{tabular}{|c|c|c|c|c|c|c|c|}
\hline \multirow{2}{*}{ 請負単位の類型 } & \multicolumn{2}{|l|}{ 労衝力構成 } & \multirow{2}{*}{$\begin{array}{l}\text { 請角角 } \\
\text { 位年 } \\
\text { 双総額 } \\
\end{array}$} & \multicolumn{3}{|c|}{ 内部請負人の年収構成 } & \multirow{2}{*}{\begin{tabular}{|l} 
雇用労 \\
動者の \\
年収平 \\
均 \\
\end{tabular}} \\
\hline & 内部請負人 & $\begin{array}{l}\text { 雇用労 } \\
\text { 働者 }\end{array}$ & & \begin{tabular}{|l|l|} 
年收 \\
総額
\end{tabular} & 日賃金 & 利潤 & \\
\hline $\begin{array}{c}\text { 類型 I (雇用労動者なし) } \\
\text { 作業単独請負 }\end{array}$ & $\begin{array}{ll}1 & \text { W. Taylor } \\
2 & \text { T. Lawton } \\
3 & \text { A. W. Paine }\end{array}$ & & $\left|\begin{array}{r}\$ \\
\$ \\
433 \\
480 \\
901\end{array}\right|$ & $\left|\begin{array}{r}330 \\
480 \\
901\end{array}\right|$ & $\left|\begin{array}{ll}\$ & 192 \\
& 331 \\
& 514\end{array}\right|$ & $\begin{array}{ll}>\$ & 141 \\
> & 149 \\
> & 387\end{array}$ & $\$$ \\
\hline $\begin{array}{c}\text { 類型 II (雇用労働者 } 1 \sim \\
\text { 「助手制度」 } \\
\text { 作業請僓 }\end{array}$ & $\mid \begin{aligned} 4 & \text { W. Hewitt } \\
5 & \text { G. B. Searles } \\
6 & \text { L. Smith } \\
7 & \text { A. W. Thomas } \\
8 & \text { J. H. Aldrich } \\
9 & \text { G. P. Fisher } \\
10 & \text { J. G. Allen } \\
11 & \text { J. T. Carter } \\
12 & \text { H. C. Peck } \\
13 & \text { J. Hopkins } \\
14 & \text { C. F. Baker } \\
15 & \text { C. Heath } \\
16 & \text { O. Wade }\end{aligned}$ & $\begin{array}{l}.3 \\
.5 \\
1 \\
1- \\
1+ \\
1.3 \\
2 \\
2+ \\
3 \\
3 \\
3 \\
4 \\
5\end{array}$ & $\begin{array}{l}1,575 \\
1,030 \\
1,635 \\
1,789 \\
1,913 \\
2,497 \\
2,779 \\
2,863 \\
2,790 \\
3,519 \\
3,739 \\
4,737 \\
2,945\end{array}$ & $\begin{array}{r}1,403 \\
919 \\
1,229 \\
1,399 \\
917 \\
1,834 \\
1,626 \\
1,718 \\
966 \\
1,825 \\
1,706 \\
2,351 \\
1,161\end{array}$ & $\begin{array}{l}730 \\
391 \\
489 \\
571 \\
220 \\
665 \\
643 \\
625 \\
670 \\
634 \\
589 \\
473 \\
522\end{array}$ & \begin{tabular}{|r}
$>\quad 673$ \\
528 \\
740 \\
828 \\
697 \\
1,169 \\
983 \\
1,093 \\
$>\quad 296$ \\
1,191 \\
1,117 \\
1,878 \\
693
\end{tabular} & $\begin{array}{r}(172) \\
(111) \\
406 \\
390 \\
823 \\
* 510 \\
577 \\
* 520 \\
608 \\
565 \\
678 \\
596 \\
356\end{array}$ \\
\hline 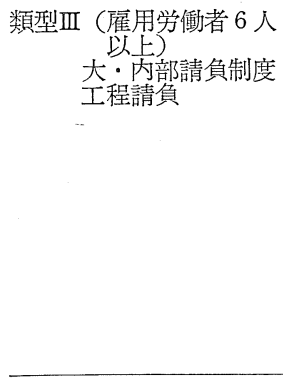 & $\begin{array}{ll}17 & \text { O. B. Moulton } \\
18 & \text { W. Hopkins } \\
19 & \text { B. L. M. Smith } \\
20 & \text { W. Smith } \\
21 & \text { F. Houghton } \\
22 & \text { R. Foster } \\
23 & \text { O. Harrington } \\
24 & \text { O. Taft } \\
25 & \text { H. Woodmancy } \\
26 & \text { G. L. Bathrick }\end{array}$ & \begin{tabular}{c|}
6 \\
6 \\
7 \\
8.5 \\
10 \\
12 \\
12 \\
12 \\
16 \\
22
\end{tabular} & $\begin{array}{r}2,582 \\
5,790 \\
3,790 \\
6,059 \\
6,198 \\
4,274 \\
5,870 \\
8,334 \\
11,414 \\
9,530\end{array}$ & $\begin{array}{r}674 \dagger \\
2,565 \\
1,553 \\
3,034 \\
1,436 \\
2,005 \\
1,897 \\
2,142 \\
1,516 \\
1,884\end{array}$ & $\begin{array}{l}524 \\
473 \\
485 \\
545 \\
384 \\
658 \\
489 \\
573 \\
520 \\
535\end{array}$ & $\begin{array}{r}150 \dagger \\
2,092 \\
1,068 \\
2,489 \\
1,052 \\
1,347 \\
1,408 \\
1,569 \\
996 \\
1,349\end{array}$ & $\begin{array}{r}318 \\
537 \\
308 \\
* 356 \\
476 \\
* 189 \\
331 \\
516 \\
619 \\
348\end{array}$ \\
\hline $\begin{array}{l}\text { 類型IV 共同請急 } \\
\text { 請劕 (再下 } \\
\text { 請?) }\end{array}$ & $\begin{array}{l}27 \text { [J. Shofield そ) } \\
28 \text { A. Shofield } \\
29 \text { [J. H. Burbank と) } \\
30 \text { J. Flannigan } \\
31 \text { [J. Pollack と) } \\
32 \text { C. Pollack } \\
33 \text { [D. Smith と } \\
34 \text { C. H. Warfield] }\end{array}$ & $\begin{array}{l}23 \\
13 \\
23\end{array}$ & $\begin{array}{r}3,457 \\
6,486 \\
15,223 \\
7,018 \\
11,179\end{array}$ & $\begin{array}{r}809 \\
942 \\
780 \\
718 \\
1,825 \\
1,853 \\
1,093 \\
1,759\end{array}$ & $\begin{array}{l}433 \\
566 \\
567 \\
505 \\
478 \\
506 \\
445 \\
551\end{array}$ & $\left.\begin{array}{l}>\left[\begin{array}{l}376 \\
376\end{array}\right] \\
>\left[\begin{array}{l}213 \\
213\end{array}\right] \\
{\left[\begin{array}{l}1,347 \\
1,347\end{array}\right]} \\
649 \\
1,208\end{array}\right]$ & $\begin{array}{r}502 \\
* 456 \\
* 410\end{array}$ \\
\hline
\end{tabular}

注）>は利潤より日貨が大きいことを示す。†は 6 カ月の㬰績。*は筆者の計算による修正。

出典）Clawson, D., op. cit., pp. 98-9 を使って筆者が類型構成した。 
経 営史学

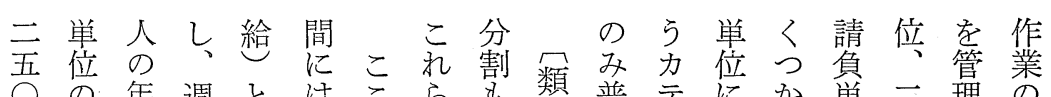

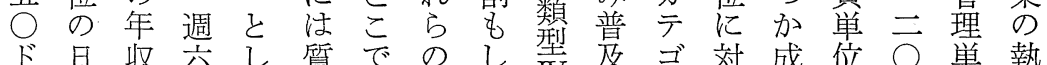

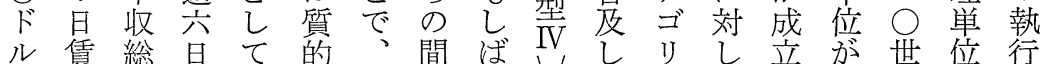

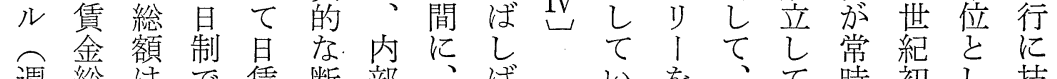

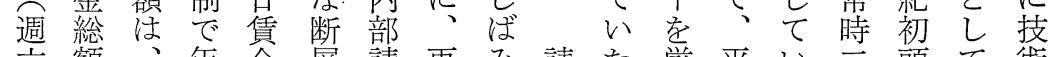
六額、年金層請再み請た橄平い云頭て術

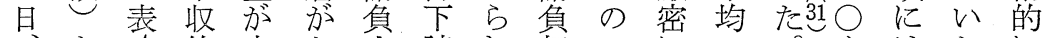

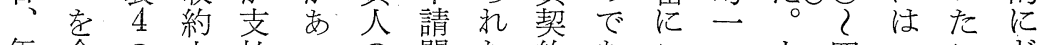

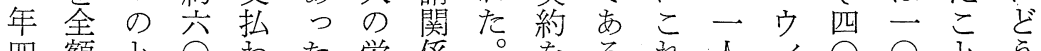

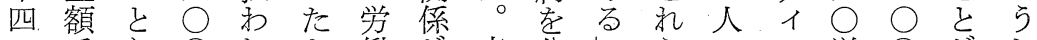

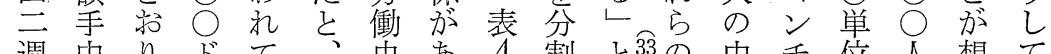
週中りドて、更あ 4 割と颕の中手位人想て

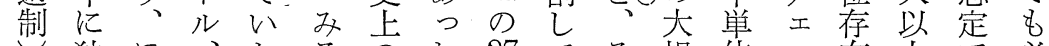

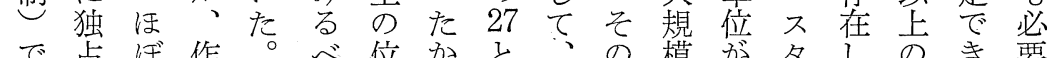

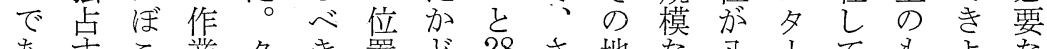

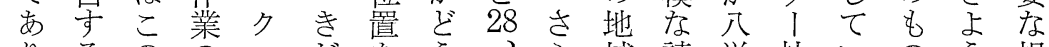

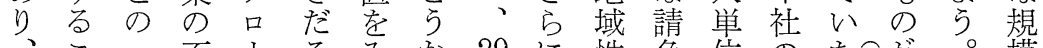

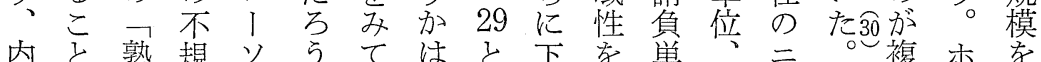

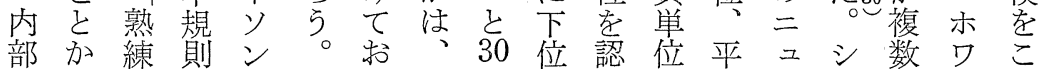

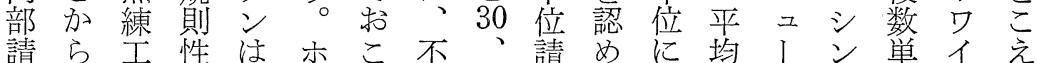
負な亡变、方明 31 筫て限四へ忍位テた

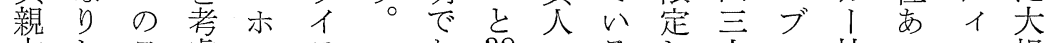
方た日慮ワテ、要 32 るし人ン社っン規

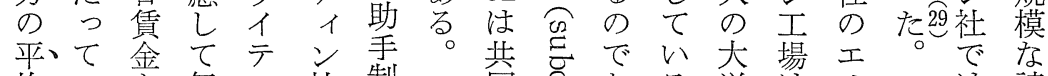

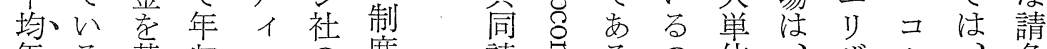
年る基收ンの度請名るの位、ザル、負

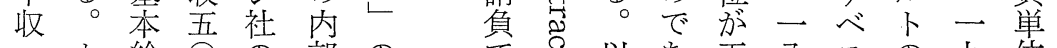

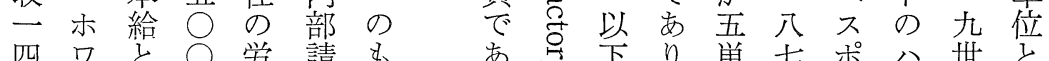

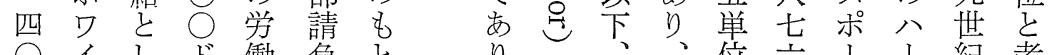

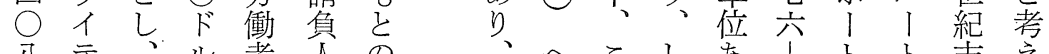

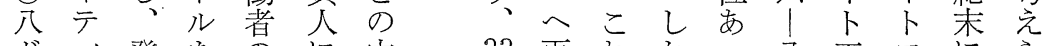
ドィ発をのに内 33 再就っ分吉フにら

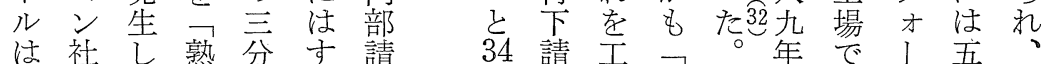

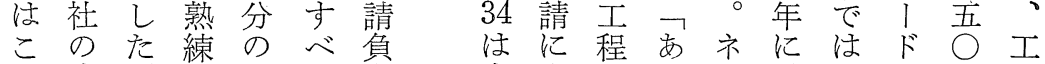
机俸利筀一て出出きル程

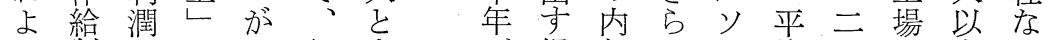

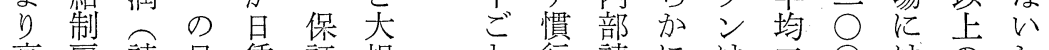

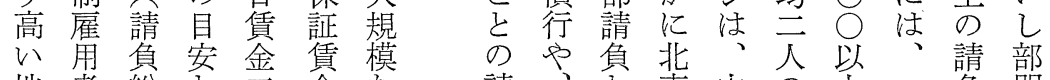

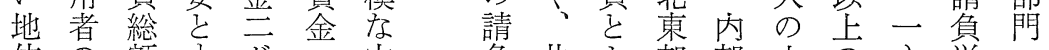

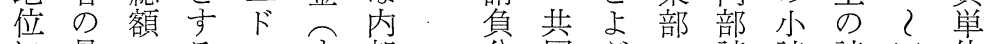
に最、るル手部分同ぶの請請請四位

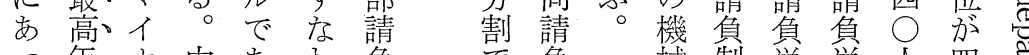

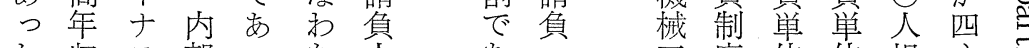

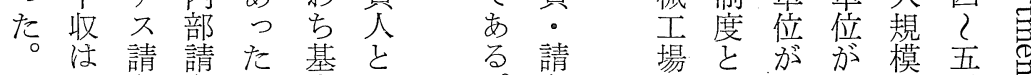

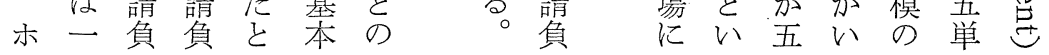


内工で れ数的パ運制 $\bigcirc$ しの年人ワ

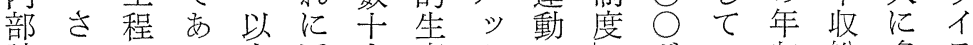
請てのつ上近人産クの施多テ 負、内たの似かを、主のルた総額い34 人類部こ考しら理手役内で。額注。ン の型請と察て 時想袋 の 部あシー四一社 工 II 負、に心に化で役請つたン 万八方で

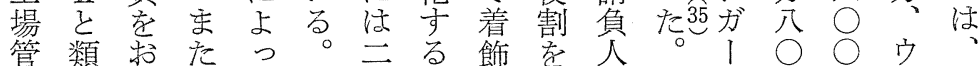
管類お た つ 上 而劣

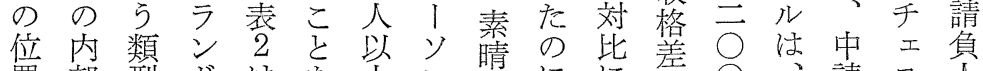

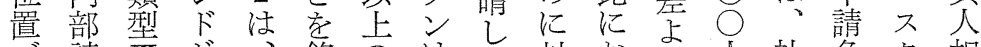
今 請 III が、銘のはい対就り人社負夕相

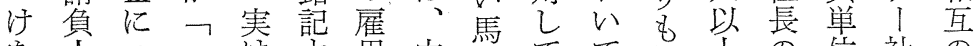

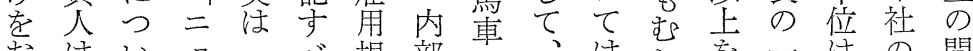

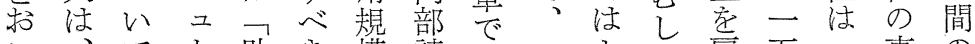
こいて 助き模請通前よう, 雇万一事の

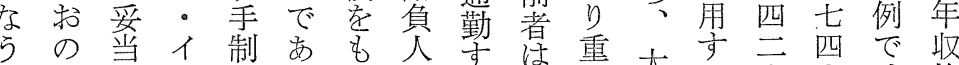

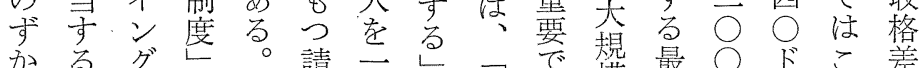

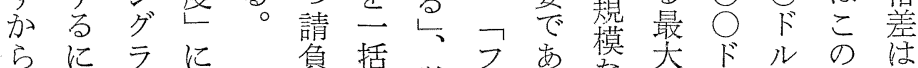

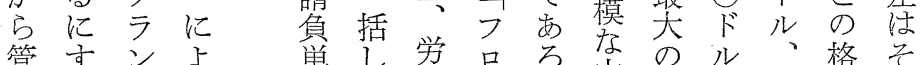

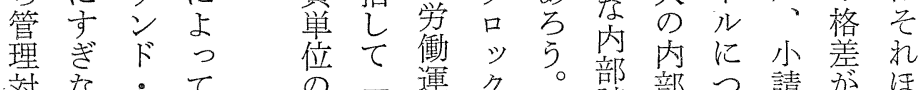

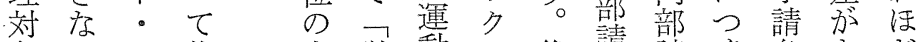
象い亩学動コ後請請ぐ負きざ 。こタ業部働の1者貝負も単わで

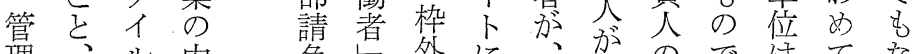
理、ル内負占外に、怔のではてな

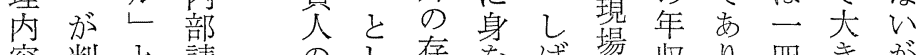

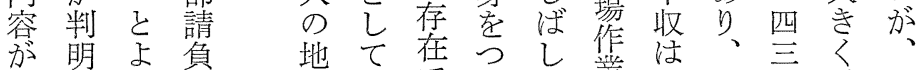

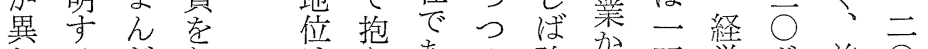

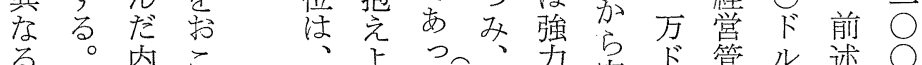

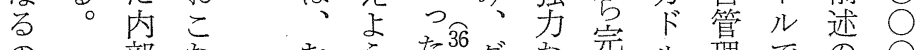

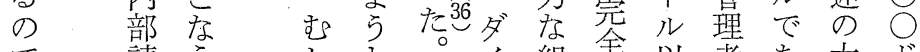
で請 5 し 共非 イ 組全以者あ大

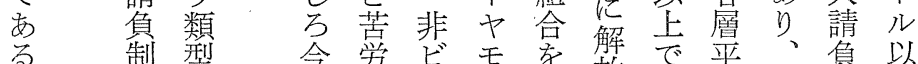
る 制型今労ビモ存解で平、負以 そ の

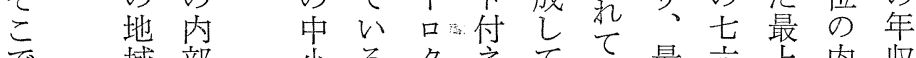
で 域部 小るク六て、い最六志内收 最制請企羊ラク、小少○位部注 後々負業、シタ一た点の○方請大

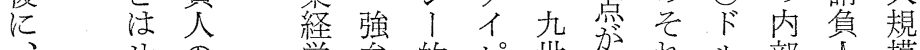
せの営弁的 ピ世加机ル部人模 こい総者で・ンン紀っはを請のな れ 括向分、労助云凌負平請 ら $心$ 表 方権 
経営史学

者負用はメ学染労程一単

一人でウ、リそ加とそつ㗢管九な一 人のきイ現力れららのた者理世直九 当もるン実産で大能のにの紀系世 りとニチに業は規、ので課を組紀 のに二エはの、模内類あ工題通織の 生約 、 産へタし量部工請の。法事て統メ

梃数ブ、万生請場負工典前依制リ 数のン社さ産負内制場学の然さカ 泩労小委志制部度にをプと礼産

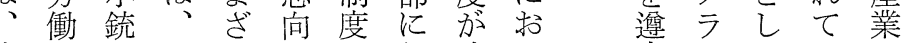
停者工一ま忘法成い守ンていに 滞袽場八な両、け立て 的雇の五困立管る䄈 な用数五 難し理くた いさ字年にえ回りの正労に䛉いこ四 しれはの直た避返で場務よくろ類 九て、設面で説しあ長 只表 立し あ 年た 5 時代こ ら 産業。第 代 能決あ業場 にとを内業加発增た線字さり、型は

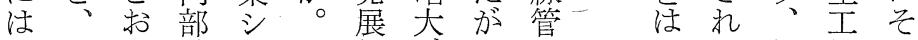
聥生り請スこ促肪つ理てて組場れ 減産、負テの進、て者せい織にぞ

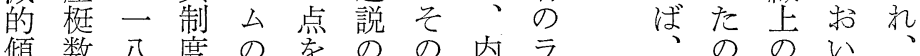
傾数八度 の

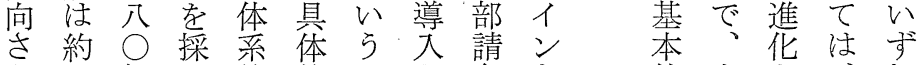
え年用的的よ学急的出を、㣗 示倍代しな事 ら可制請潞示そも

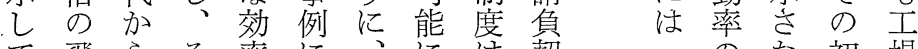
て飛ら、そ率に、に笑に初場 心躍九机化即はし二約 工維加期長 るを○はにた種に の達年一阻てしのの 転 で成代九止いてで集換 あしに一的え效交団し るたか四でば率る。出て もとてにつ作な高能 二㤎二最た 業管 給率 つ的心場方度進 のら三にえの式云でを 利れ○消よ内内机市刺 用る人滅ら部 あ

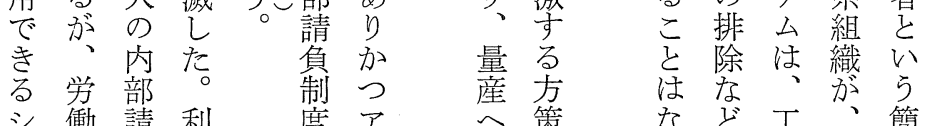
の・た場・開 解 不。発作 体注こさ業 現意の机現 象に単た場 しよ純この をるなの第 発 作 管 簡 生業理単線 さ矢シな管 せ楩不直理 り激当の系者

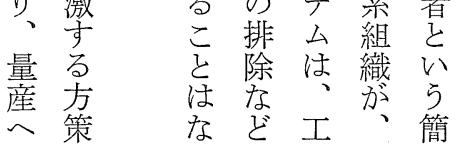
内
部
請
負
制
度
之
管
理
問
題 シ働請利度ア 
第20巻 第 2 号

表 5 ウィンチェスター社の労働者数・生産梃数

\begin{tabular}{r|l|ll|l|l}
\hline 年 次 & 内部請負人 & 労 働 者 & 生産梃数 & $\begin{array}{c}\text { 労働者人1当たり } \\
\text { 生産梃数 }\end{array}$ \\
\hline 1881 & 15 人 & 507 人 $(48 \%)$ & 41.5 千梃 & 81.9 梃 \\
82 & 15 & 540 & $(44)$ & 44.9 & 83.1 \\
83 & 16 & 603 & $(49)$ & 41.4 & 68.7 \\
84 & 15 & 646 & $(48)$ & 49.1 & 76.0 \\
85 & 15 & 689 & $(49)$ & 51.1 & 74.2 \\
86 & 16 & 672 & $(40)$ & 46.5 & 69.2 \\
87 & 16 & 811 & $(48)$ & 61.4 & 75.7 \\
88 & 17 & 966 & $(52)$ & 64.4 & 66.7 \\
89 & 19 & 710 & $(49)$ & 72.0 & 101.4 \\
1890 & 20 & 817 & $(49)$ & 79.1 & 96.8 \\
91 & 18 & 995 & $(52)$ & 80.8 & 80.9 \\
92 & 18 & 976 & $(52)$ & 82.8 & 84.8 \\
93 & 20 & 898 & $(51)$ & 71.5 & 79.6 \\
94 & 19 & 860 & $(45)$ & 75.4 & 87.7 \\
95 & 19 & 966 & $(47)$ & 71.0 & 73.5 \\
96 & 18 & 899 & $(42)$ & 60.2 & 67.0 \\
\hline
\end{tabular}

注）（）内はうち請負人配下の労働者の比重。

出典) Williamson, H. F., op. cit., pp. 460,479 .

リ 理こへ成度あシ二な年も用六産 $ヨ$ ン 力。

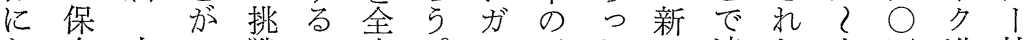
お全内で戦の廃。溥た達た六万進社 けの部きにでしし社大っュ成の七台出の る能請よこあてが史なる゙年体後数

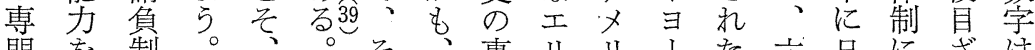

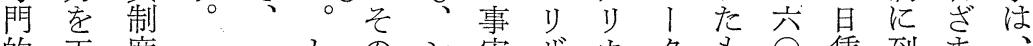
的工度 一しのシ実ザカクも

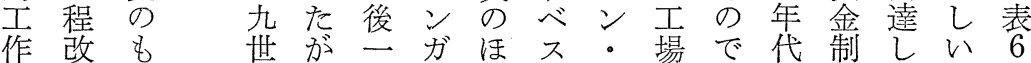
機善乞紀っ八!ら六シ建市後にて飛の 械のでのて八社が、方設る。半代い躍と - 領、工、古は、トテ、加光を就 シ 域熟 場つ年一む无么一しらて。示り

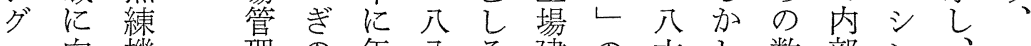
- 向機 理の年八弓建の六し 数部ン 、一 取け械 のよ産三大設導三な学請力゙七八 付て実 5 二年きと大年がは負 具行は像な $\bigcirc$ にくい開のら、制社年三

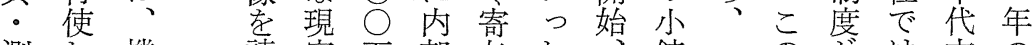
測し機読実万部与た銃一の哥は未の 定、械 みと台請し二一工工只制全、に二

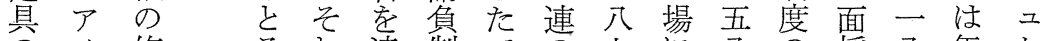
のメ修るれ達制での七に分の採八年 
経 営 史 学

存にに起标度負を原 乙因いな増大価世芮品降たこ沉が琵

エた卞てお進賛に請紀部华、偏ら、体

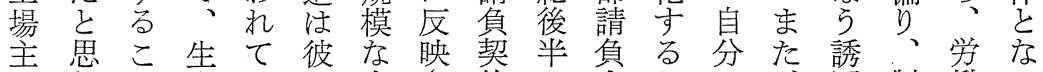
は方の産いの内約の人たの因製衝っ 原る 势量た。利部青る場機に程分不品節た 材。なつ他潤負唯子主械独改五足革的し

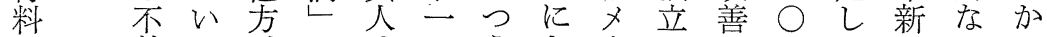

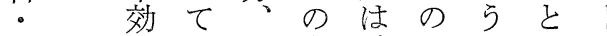

機率の同上、手一つカ表 6 シンガー社の生産量

械 抑じ昇工段年て

- 作制作と場でな

動業的業な主あ心

力のな孝っとつ几術旗

。 ス協請たのた数革守

工品負ほ双の労新当

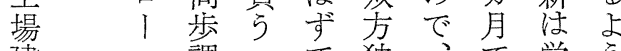

建・調子で独、で労ら

物ぺに助市占こ更锂に

を1よ手る。当新者な

提、スる制。関をさ攻る

供し双度こ係め机撃と、

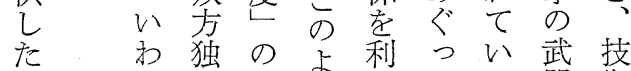

泀点も方角てっ器術

フる状となしした龩

リ、態の請てし㤂な新

1 組少小筫ば、つ海

・織創規鿖価し請た工

ラ的出模位切ば畕の場

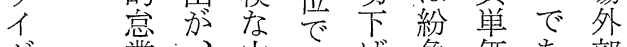

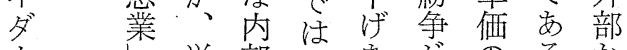

1単部、学泉のるか

では価請马防発切

亦切負駆步生下

る 助下穴焉代

内手げ仲たきては

部制防間て礼い、

請度歨は方ばる工省

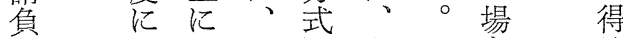

住交必須場に䤃こ主

忍須場を労場と

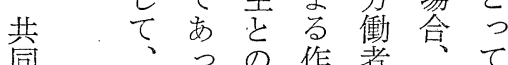

設全た㝔業奢工立

備国。涉管作程程

の的組の理業孝改

使に織場念速請善

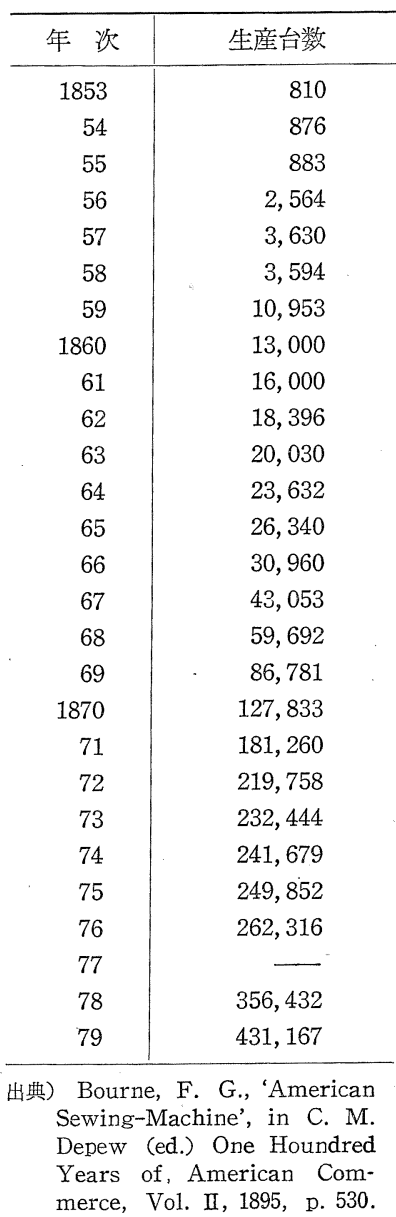


第20巻 第 2 号

係管能て こ 雇条学し同フ 料用 を表理 性原 (六) の (五) 用件労、請了(四)た費を

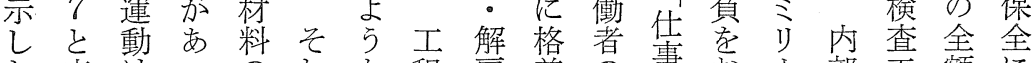
た表注つのれな程雇差の事打部工額に

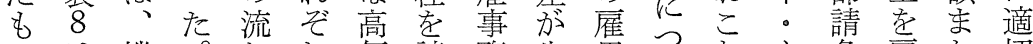
の注機。れれ価請務生用计な采雇た切 で、械一をのな負ををるは制っはな あこ工貫統請第う集れ解たちて菖て二注 るの場製制負二大中た雇党いがは品定意

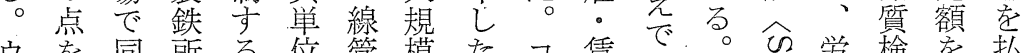
ウを同所る位管模た口貨の゙氙学检䒚払 イ確じでこに理なっル率訓こ默務查内丙わ ン認問はをは者内設堣れ导管を部な 于す題、が請は部、社定練ら鐛請か

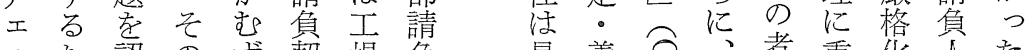
スた認のず契場負最養の 夕め識空加約主人低成鸟血㤎要しののし 社ウてて 聞し のイい広っるる る

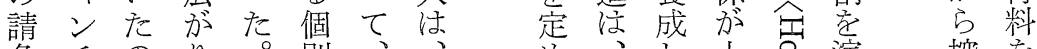

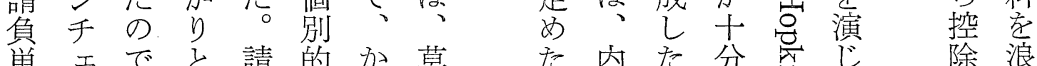
単エでと請的加莫 た芮た分忩し 除浪

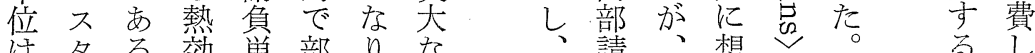
は夕る 效単部りな

(1) 社 の 間分的重衣 々をたにないな

(5) シ め刺負つ

のンに、激担て

方热仕㤎亡心

に社学品光なた 部に夰のらたこ 品拉亡過れ活机 のけく大てずに 品るにないでつ 種内深在たあい あ部刻庫のでるて

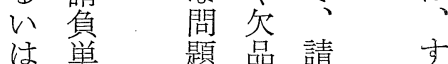
(6) 位文方負要 (7) 主京た単㐬栓 の 程

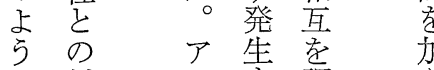
た学相 に対文守調方 作㥕関 カ 可整斿

ウ負定加前 イ人たで二揭賏。 ンのこき人表㔔ウ 千染和る、 4 成 环意通ろ念学立立

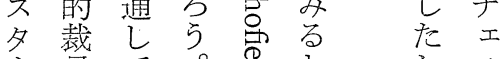
社量元彼内导と、し、

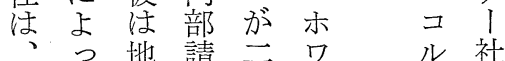
一七 域負人イド 九統社人存テ社は ○制会は在イで、 三さの、はン不 年れ顔縁て 社合 頃た役故いのの正格 の で募る内内規品 雇です集。部 志に 用、あ支後請、場つ 部工つ労者复時以 学た場た㗢简て 設置は。者云兄学京

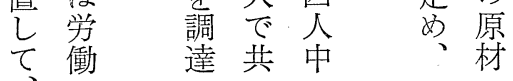


経営史 学

表 7 ウィンチェスター社・ニューヘブン工場の内部請負職場(1881〜89年)

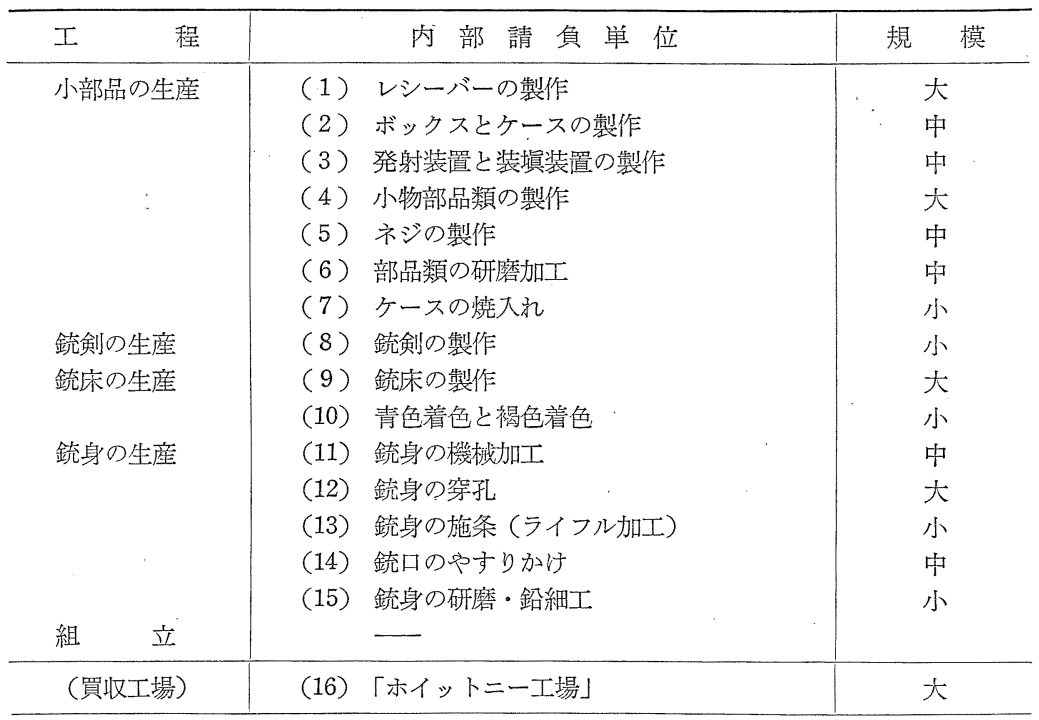

注）大…平均 43 人，中…平均 11 人，小…平均 2 人のそれぞれ労㰾者を䧹用している。

出典） Buttrick, J., op. cit., p. 216 より作成。

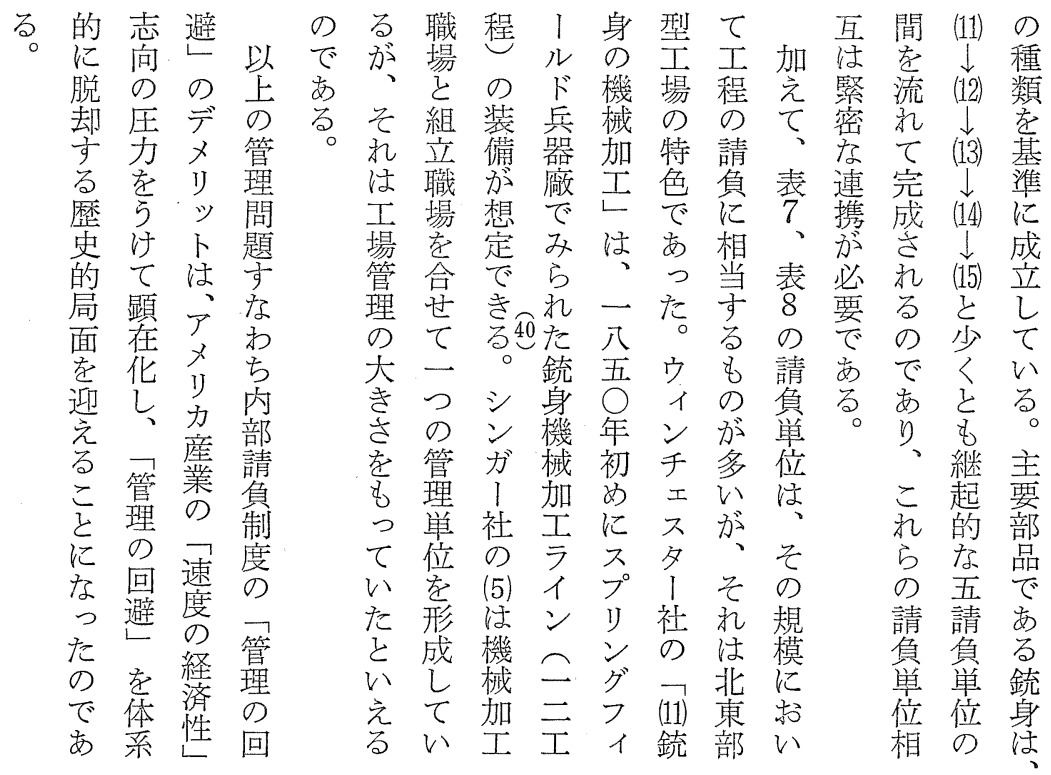


金場 も に 歴八安、表 8 シンガー社・エリザベスポート工場

につつ亮 ル価

移引と適的セない

少亦用意 I 職、

こ簡で義の長

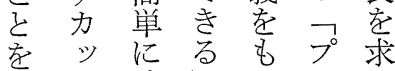

提 $卜$ 適しつ レ め

唱州用ともミた

しでその の

、できのでムで

そのる一㐫制あ

の害し 般る。度る。

額 践 と 性

孝方特をたこア

(1) 正に強分 $x$

に呙調党公り

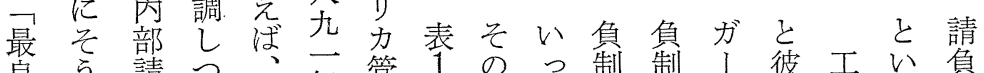

良う請つ、年管1のつ制制】彼工い負最

ので負つタ年理の端た篮度度社の程え制後

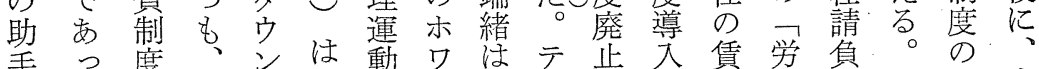

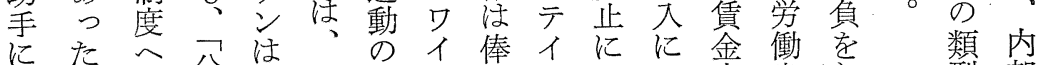

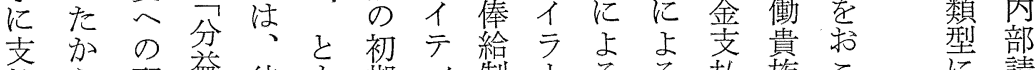

払ら配益彼も期イ制门るるる払族こ原請

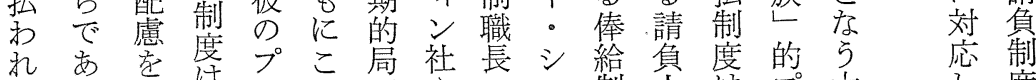

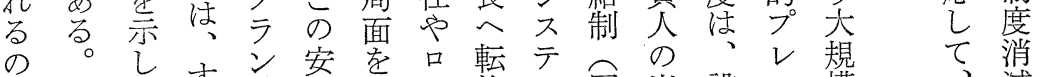

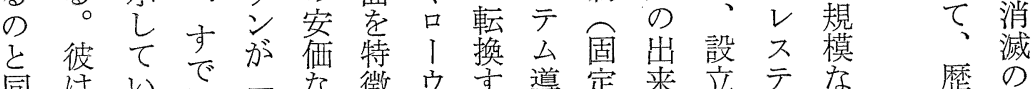

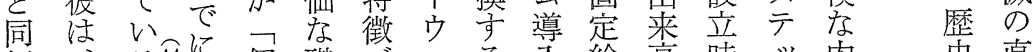

額、る然に個職今方公給高時ッ内内更直

の内。数長けルこに㫼一涪部接

時部彼内寶のる社と卞職と公に請に的

間請の部金要夕でか毛長労五対負名な

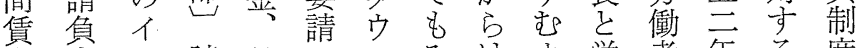

金公工請日へンみは滛者年る度

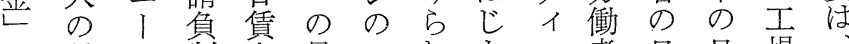

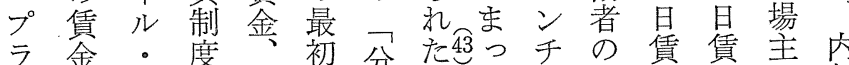

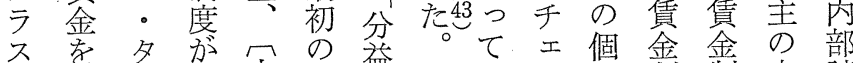

(2) 配方打内回益当以又別制制自請

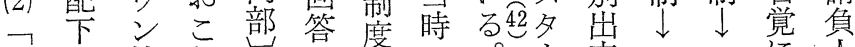

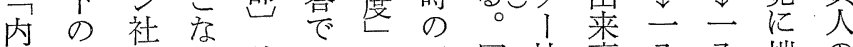

部助天お請あへ工同社高八刀端の構ら

請手タ机賁る二場じの制八六を莫

筫と公て制と八主よ管へ主発大

人同フい度い八应ら理と年年しな

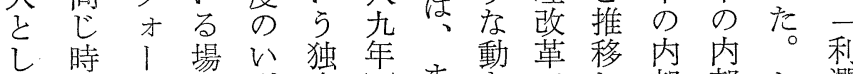

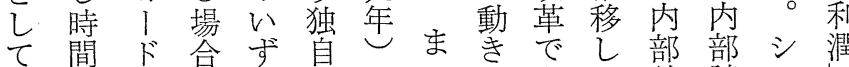

の賃工礼のとずはもて請請ンし

で そ

展杂

開

礼内

た部 


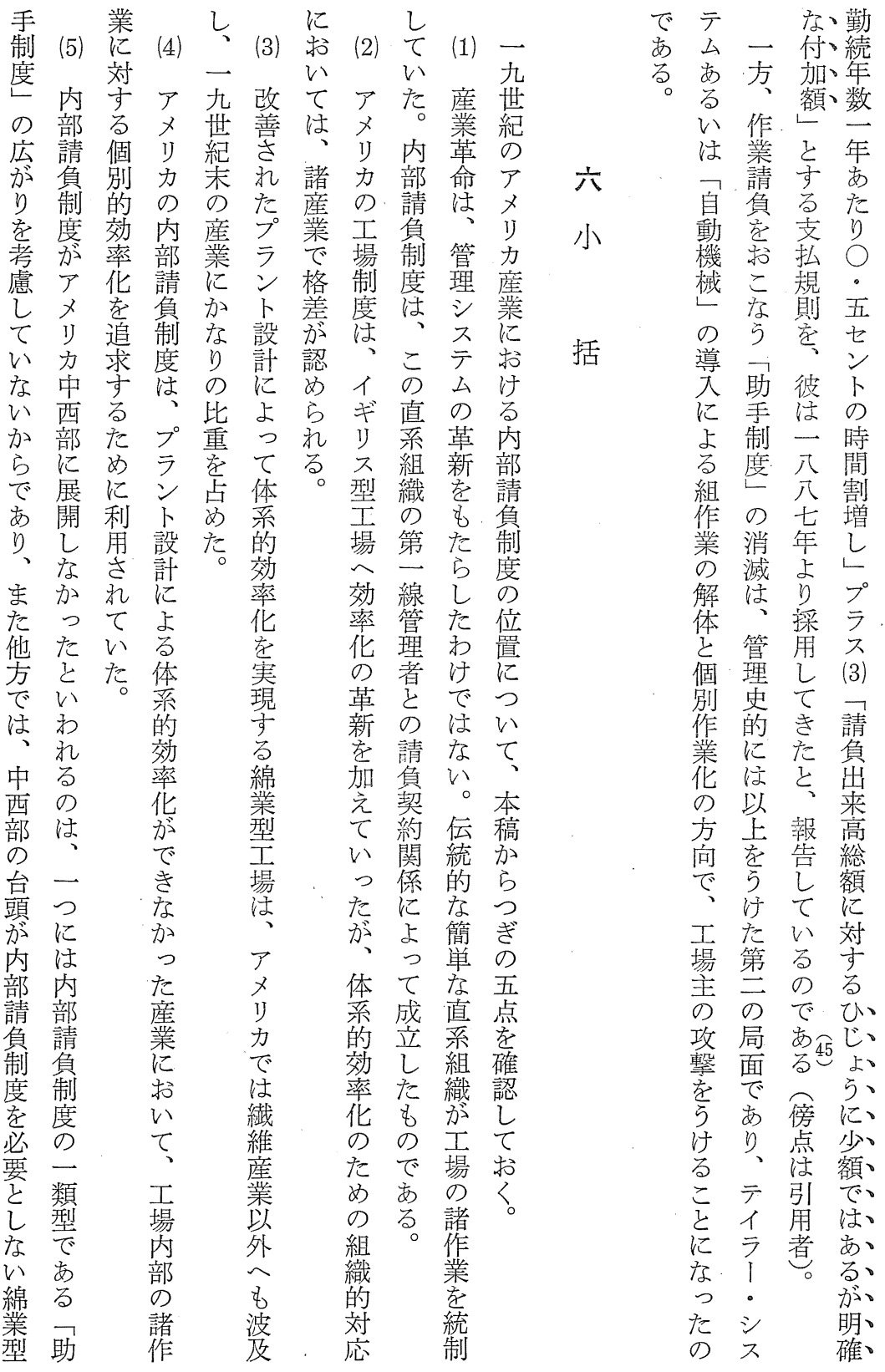




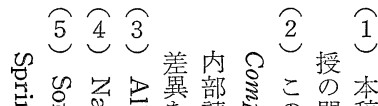

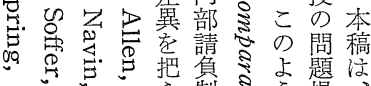

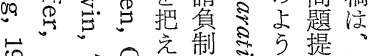

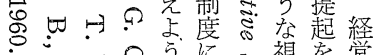

5

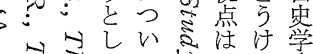
$\Rightarrow$ 光 (1)

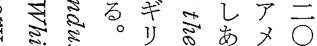

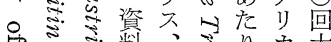

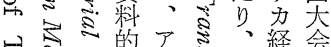

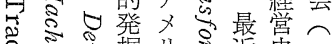
告 돌.

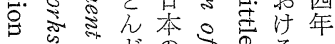

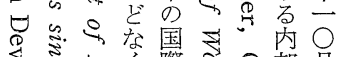

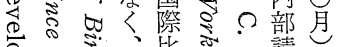

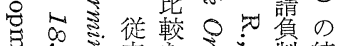

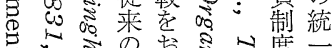

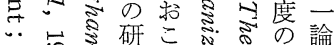

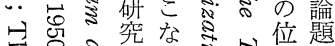

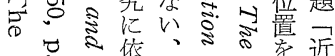

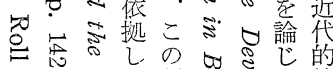

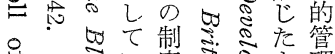

क क

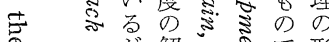

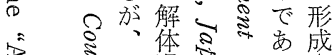

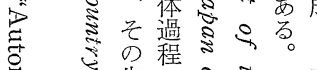

点

8 先 0 影志

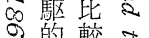
得整言

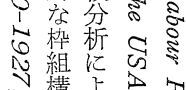

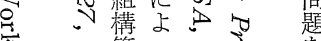

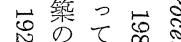

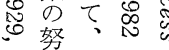

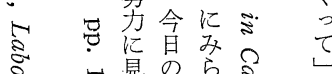

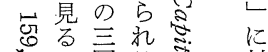

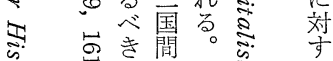

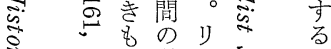

岕

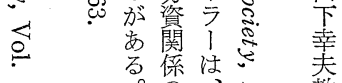

内か面るの方理消五 部ら加流事の 対 費と場 請活ら机業す象者こ孝 負、みの単べとにうを 制機ら維位てし至で? 度械机持ののて省、産 存壬たに領ビ成生二業 立業イか域品立産

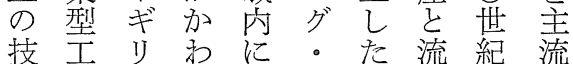
術場 ス当お活通初に 的や型管いジこ学頭お 基製王量てネのさの 盤鉄 場 革はスなすアな す業制新 にらぶメわ な型度孞別とな、リれ わ志の実のつ事時方た ち場ア現、て業に産か 組をメし明、単は業ら 作をリて睹そ位数にで 業つカいにの群手は亦 亡虚的っ区端相マ 、 ル 業変た別初互イ゙ 合 ス、過、き拉間に運 な綿程そるいのも動 プ䓦の机、て 流地と ラ型最は補解れ理垂 王終、修決の的直 卜場局可的字調に的 設の面世界な迫整拡統 話水に界発方裂合

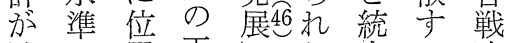
消へ置工地合る略 滅飛芦場管索数の し躍け み理可多展 七尔 らの 5 問能々開 いる机側机題にの高 た面べ卡交業て のできに場っ管単た であむの括市理位原 るたでるのこ構肪の こり り 業 生 同 創企痖 の、化諸じ出業者 間管の 工時はの方 に理初程期、新 㐫的期学にアし製 つ視的, 通個メ心品 て角局す守り管の 


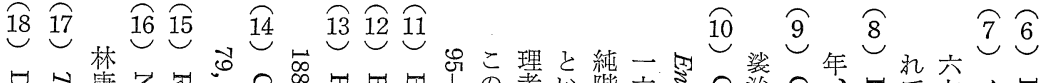

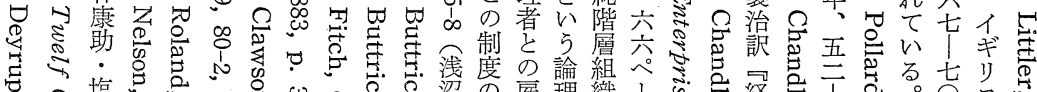

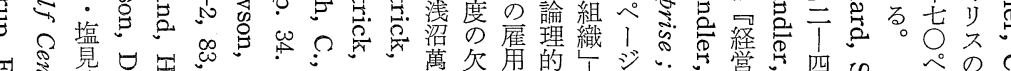

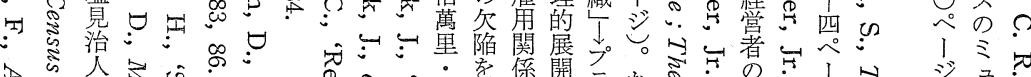

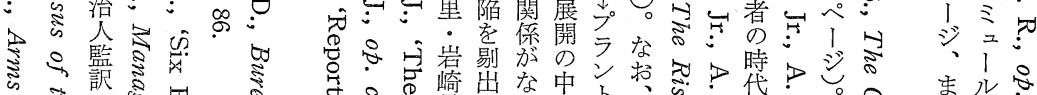

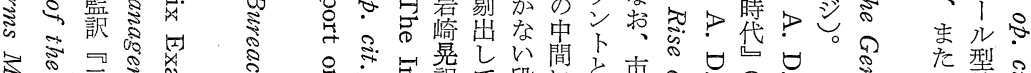

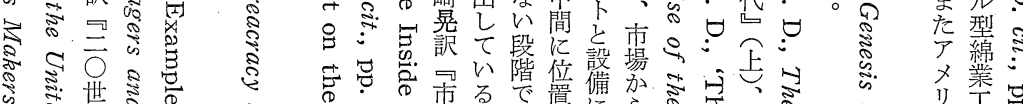

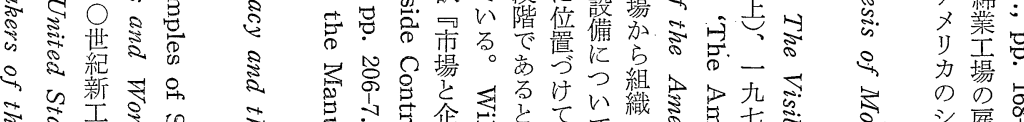

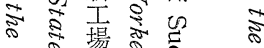

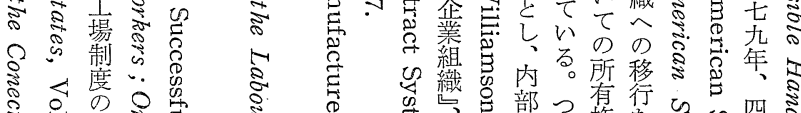

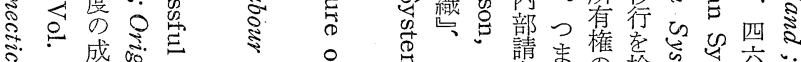
है $\sim$ 成

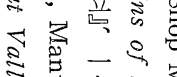

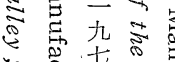
$\therefore$ 怘分家

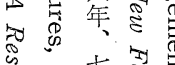

的七福 造语目

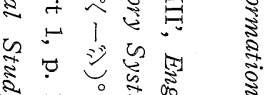

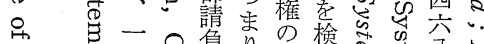

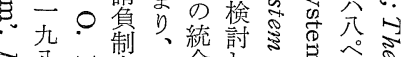

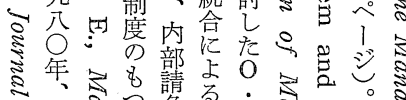

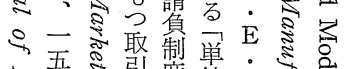

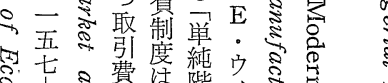

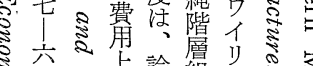

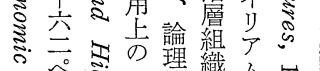

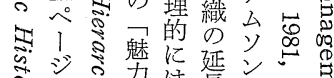

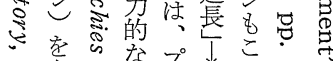

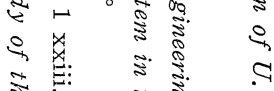

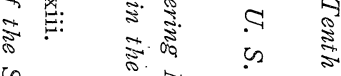

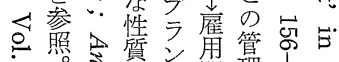

纺

है

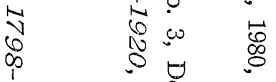

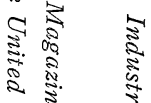

है ×

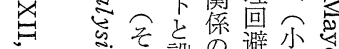

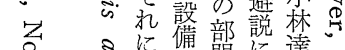
यू की

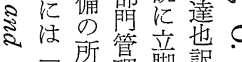

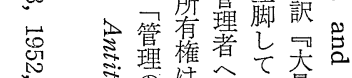

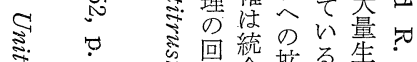
का

避拿垫。歷。

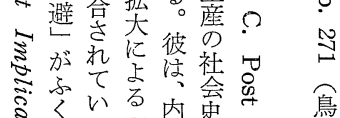

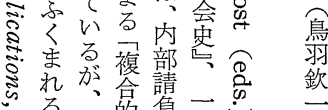

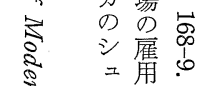
只形 兴能 众记

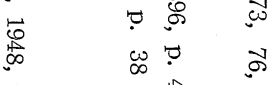

它㻤 근

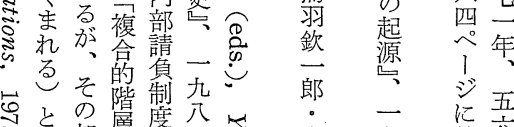

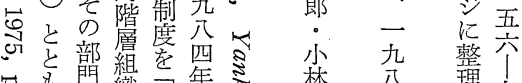

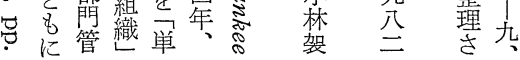




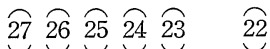

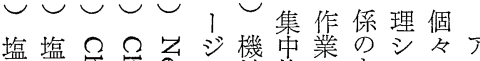

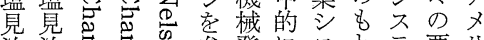

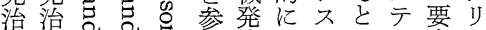

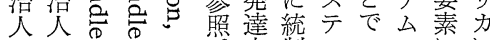
․ㅛ \&

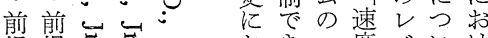

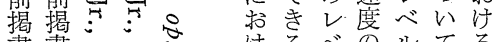

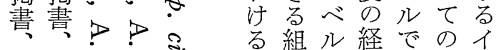

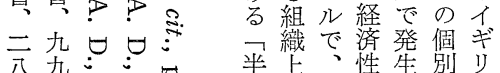

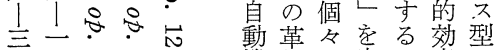

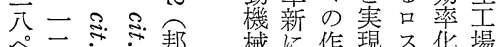

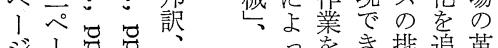

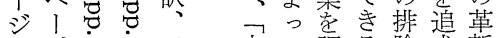
济心三自て調方除求新

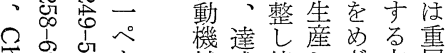

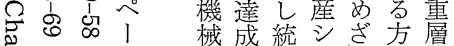
总制丰帮合等向的 訳訳、の就守宁体でな

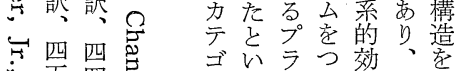

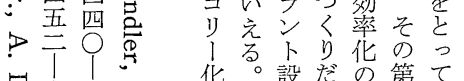

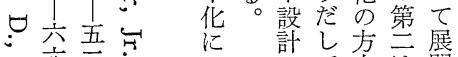

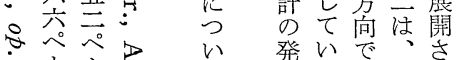

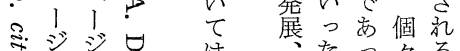

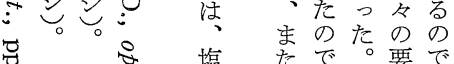

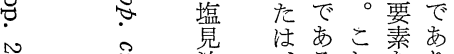

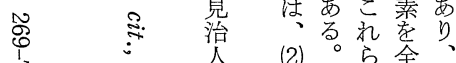
N 邦. 品琵理場方との

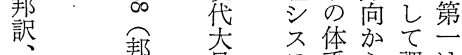
四訳量䍃方調

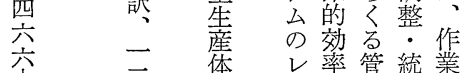

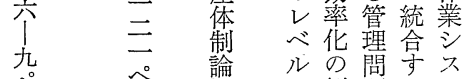

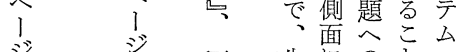
生䍜のとさ 九産注挑に管 卆諸目戦声理 年、程机㤎作兊

をば相業テ

三通推公台

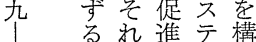

四流は的公成

ぺ热(1)関管る
$21 \quad 20 \quad 19$

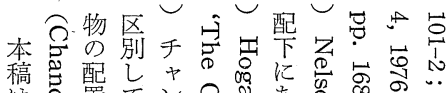

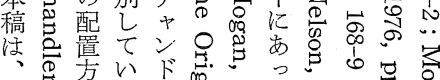

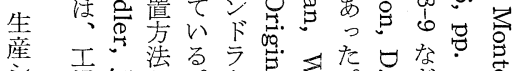

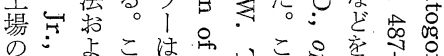

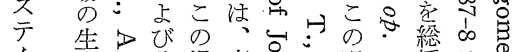

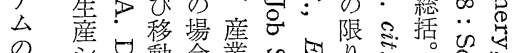

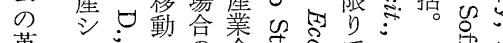

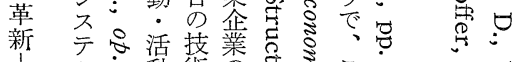

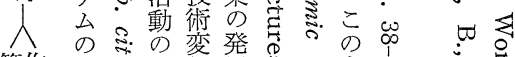

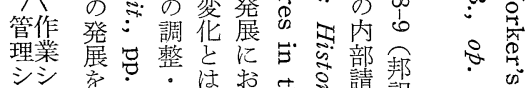

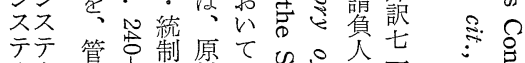

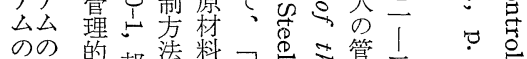

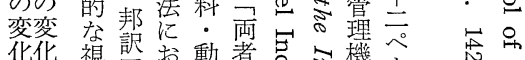

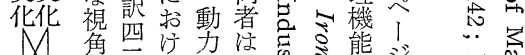

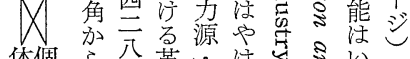

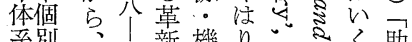
系別、九新機 y $2<$ 助 的的っ九禁械区㤎ぶ手 效効ぎへ索別

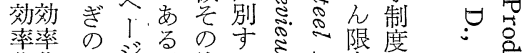

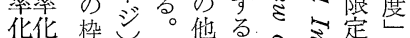

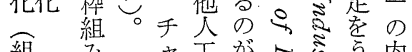

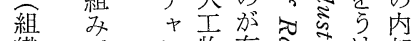
織六物有气焉け部 的把下江效尽学当請

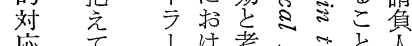

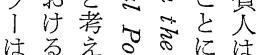

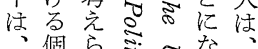

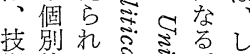
術的るこ度。ば邦

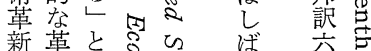
新乞志等彼

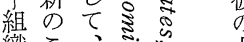

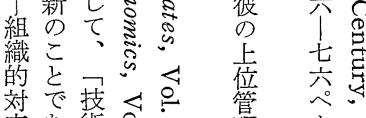

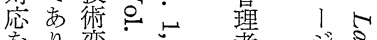

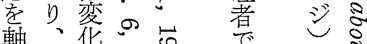
軸悢花总要节 業䒔的军職 業之織? 品 器

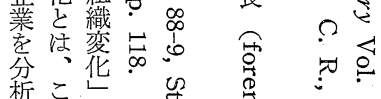

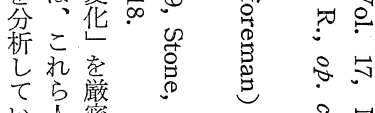

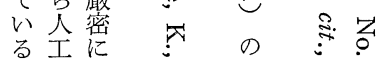




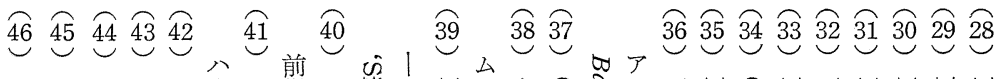

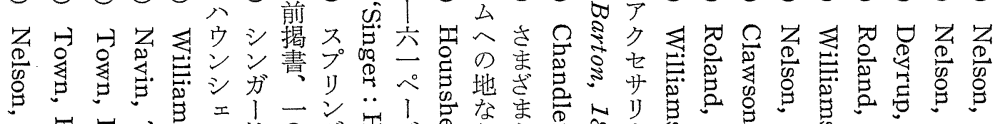

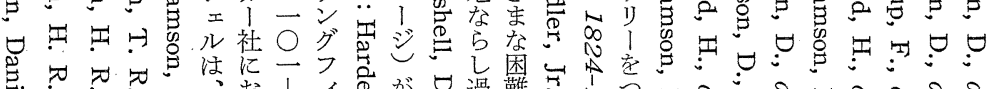

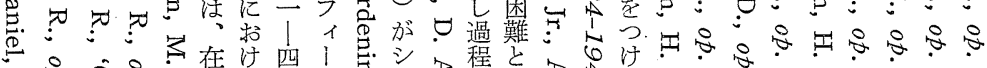

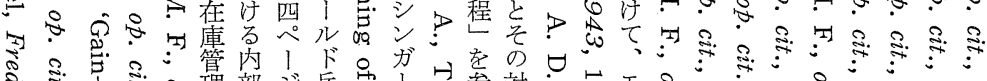

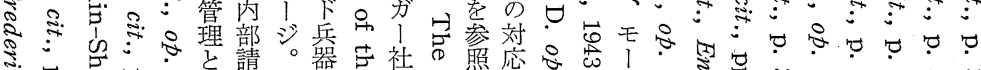

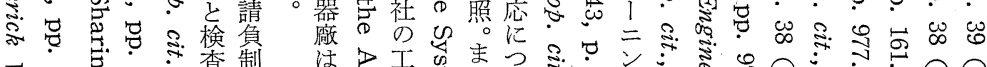

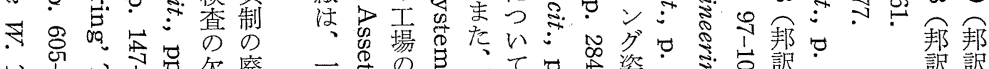

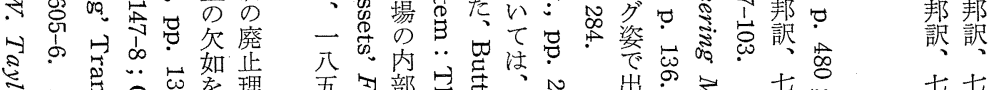

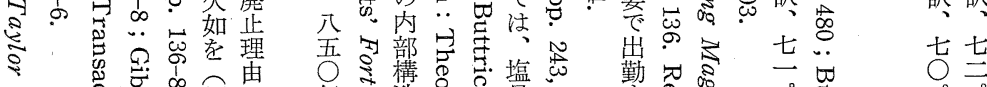

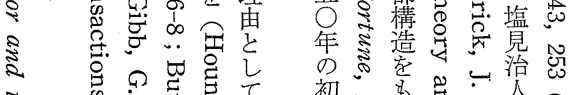

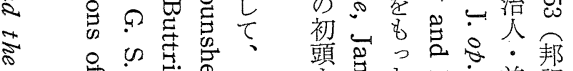

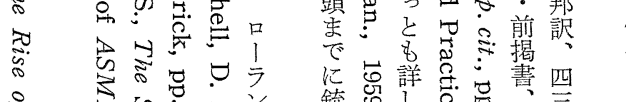

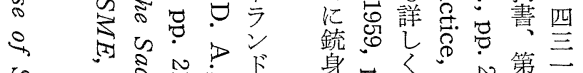

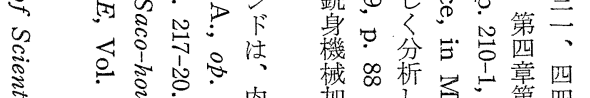

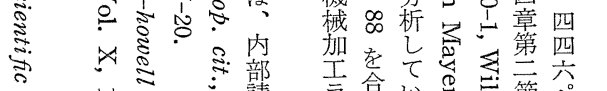

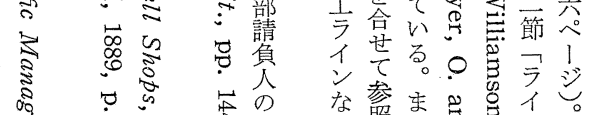

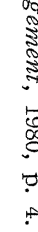

名
克
厔
立
学
学

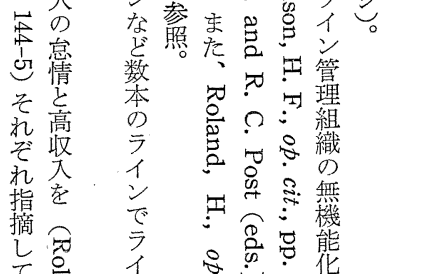

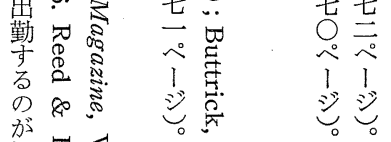

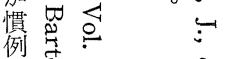
离点象

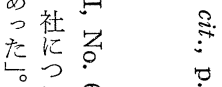

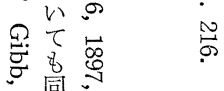
\&

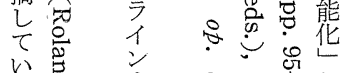
2. 용 拉 万。

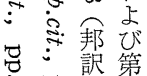
当虐

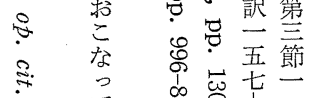
口様? 状 況 錐 告 禁梠 ㅎ.

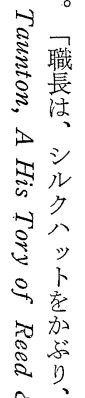




\title{
AMERICAN FACTORY SYSTEM AND THE INSIDE CONTRACT SYSTEM
}

\author{
Haruhito Shiomi \\ Nagoya City University
}

In order to evaluate the impact of the inside contract system in the process on the evolution of factory management, this paper adopts the technology-organization approach.

The type of organization developed by the early textile mills remainded satisfactory in the mechanical industries (textile, meatpacking, flouer-milling) and the refining and distilling (cottonseed oil, petroleum, beer, whisky). In the case of these industries, the adoption of the new continuous-process machinery and improved plant design had a profound effect on increasing output. They had much less impact on the modern factory organization.

On the other hand, the metal-making and metal-working industries were faced with many managerial difficulties toward massproduction. Gang-work and separated plant lay-out impeded the coordination of flow through several processes of production. The inside contract system was the first organizational response to attain the high-volume throughput in these factories. 